\title{
Review
}

\section{Agricultural Waste-Based Biochar for Agronomic Applications}

\author{
Ghizlane Enaime (D) and Manfred Lübken *D \\ Institute of Urban Water Management and Environmental Engineering, Ruhr-Universität Bochum, \\ Universitätsstraße 150, 44801 Bochum, Germany; ghizenaime@gmail.com \\ * Correspondence: manfred.luebken@rub.de
}

check for

updates

Citation: Enaime, G.; Lübken, M. Agricultural Waste-Based Biochar for Agronomic Applications. Appl. Sci. 2021, 11, 8914. https://doi.org/ 10.3390/app11198914

Academic Editor: Fulvia Chiampo

Received: 25 August 2021

Accepted: 20 September 2021

Published: 24 September 2021

Publisher's Note: MDPI stays neutral with regard to jurisdictional claims in published maps and institutional affiliations.

Copyright: (c) 2021 by the authors. Licensee MDPI, Basel, Switzerland. This article is an open access article distributed under the terms and conditions of the Creative Commons Attribution (CC BY) license (https:/ / creativecommons.org/licenses/by/ $4.0 /)$.

\begin{abstract}
Agricultural activities face several challenges due to the intensive increase in population growth and environmental issues. It has been established that biochar can be assigned a useful role in agriculture. Its agronomic application has therefore received increasing attention recently. The literature shows different applications, e.g., biochar serves as a soil ameliorant to optimize soil structure and composition, and it increases the availability of nutrients and the water retention capacity in the soil. If the biochar is buried in the soil, it decomposes very slowly and thus serves as a long-term store of carbon. Limiting the availability of pesticides and heavy metals increases soil health. Biochar addition also affects soil microbiology and enzyme activity and contributes to the improvement of plant growth and crop production. Biochar can be used as a compost additive and animal feed and simultaneously provides a contribution to minimizing greenhouse gas emissions. Several parameters, including biochar origin, pyrolysis temperature, soil type when biochar is used as soil amendment, and application rate, control biochar's efficiency in different agricultural applications. Thus, special care should be given when using a specific biochar for a specific application to prevent any negative effects on the agricultural environment.
\end{abstract}

Keywords: biochar; agricultural waste; soil amendment; greenhouse gas emissions; composting; animal growth

\section{Introduction}

The high increase in world population has resulted in a rise in agricultural activities of more than three-fold in the last five years [1]. Technological advancements and the expansion of agricultural soils to meet the increased worldwide demand for food will inevitably result in a continuous growth of agricultural activities [2,3]. Agricultural activities worldwide generate significant amounts of greenhouse gases; agriculture contributes, respectively, by 52 and $84 \%$ of the global anthropogenic emissions of methane and nitrous oxide [4]. Agriculture is often accompanied by negative effects on the environment and ecosystems. New practices are thus required to ensure the sustainability of the agricultural sector, including the sustainable management of agricultural residual materials [5]. This is consistent with the idea of the circular economy (grow-make-use-restore) [6], which, in contrast to the linear economy (take-make-use-dispose) [7], aims to eliminate wastes from a system by converting them into high added-value products [8]. In other words, the concept of the circular economy seeks to recover resources instead of importing new resources from outside of the system [9]. The worldwide challenges related to climate change, biodiversity loss, increased demand for raw materials, waste production and pollution are pushing organizations to shift their activities from a linear to a circular economy. In this context, several applications in many areas such as dairy products [10], agri-food [11], the use of fertilizers $[12,13]$ and biochar $[14,15]$ have been presented.

Biochar has been gaining increasing attention recently as an organic material that can be effectively involved in agriculture to enhance soil fertility, stimulate plant growth, and increase agronomic productivity [16,17]. Biochar is a carbon-based solid generally produced by pyrolysis of organic wastes under complete or partial exclusion of oxygen. 
Agricultural residues generated on farms as by-products of crop production are widely used for biochar preparation. The recovery of biomass harvested from agriculture is more efficient in developed countries as compared to developing countries, where the insufficient government policies and the lack of investment in waste management technologies still limit the appropriate management of these residues. The conversion of the large volume of agricultural residues produced annually to biochar could be a promising alternative to exploit their pronounced and manifold potential [18-20].

Biochar has many different aspects of application in agriculture, the main examples of which aim to increase soil fertility, increase nutrient uptake, and improve the water retention capacity of the soil. This will simultaneously improve crop productivity, mitigate plant stresses related to both salinity $[16,21]$ and toxic contaminants [22,23], and reduce dependence on fertilizers $[24,25]$. Biochar application directly affects soil physicochemical characteristics such as $\mathrm{pH}$, nutrient availability, electrical conductivity, porosity, surface area, bulk density, and cation exchange capacity (CEC) [26,27], and influences soil microbial structure by providing additional habitats to the microbial populations [28]. Biochar was also reportedly able to remediate organic and inorganic pollution in the soil by complexation or through sorption $[29,30]$. Biochar has stable aromatic organic carbon. This carbon is hardly degraded and therefore does not return to the atmosphere [31,32]. This will, in fact, minimize $\mathrm{CH}_{4}$ and $\mathrm{N}_{2} \mathrm{O}$ emissions to the atmosphere and consequently reduce climate change [33]. The features of biochar essentially depend on both the type of feedstock and the pyrolysis conditions. Consequently, many biochar types with many different properties may be produced from different types of biomasses and at a broad range of pyrolysis temperatures [34]. The high variation in the chemical and physical characteristics of biochar, despite its highly documented benefits for soils, still imposes some limitations on its applications in agriculture [35-37].

The goal of this review is to emphasize the correlation between biochar characteristics and its possible advantages for soil structure, crop productivity, pollutant removal, animal growth and greenhouse gases emission mitigation from the soil. This review also highlights the risks and key limitations of biochar with respect to soils and agricultural ecosystems.

\section{Physiochemical Characteristics of Biochar}

Physico-chemical characteristics of biochar are controlled by the type of feedstock and pyrolysis conditions $[38,39]$. Surface area, porosity, density, water retention capacity, and hydrophobicity are the main physical properties of biochar [40]. Biochar is porous in nature and generally characterized by its low bulk density (less than $0.6 \mathrm{~g} / \mathrm{cm}^{3}$ ) [26]. The pyrolysis temperature has a strong impact on biochar porosity; volatile substances are released at high temperatures, which supports the formation of pores [41]. Somerville et al. claimed that a higher porosity of wood-derived biochar is obtained, from 50 to $70 \%$, when pyrolysis is performed at temperatures from 300 to $850^{\circ} \mathrm{C}$ [42]. Biochar is mainly microporous, with more than $80 \%$ of its total pore volume being micropores [40]. The biochar surface area increases similarly to porosity with rising pyrolysis temperature. For most biomasses and under suitable pyrolysis conditions, the surface area can reach values between 100 and $800 \mathrm{~m}^{2} / \mathrm{g}$, while for biochars derived from sewage sludge, the surface area shows values below $100 \mathrm{~m}^{2} / \mathrm{g}$ [39]. The biochar's water-holding capacity is also enhanced at higher pyrolysis temperatures. However, in some works it was observed that on the biochar surface the functional groups decrease at higher temperatures, which alters the biochar's affinity to water [40]. Surface functional groups are responsible for biochar reactivity and form the interface where different biological and chemical reactions occur. Among many functional groups found on biochar surface, such as aliphatic, aromatic, hydroxyl, epoxy, acyl, ether, amido, sulfonic, and azyl groups, phenolic-OH, carboxyl, carbonyl, and ester groups are the most abundant. The association/dissociation of these groups with protons results in biochar alkalis, hydrogen bond-induced sorption, hydrophilicity/hydrophobicity, surface charge alterations and CEC [43]. The dissociation/associations of protons provided 
by biochar functional groups as a function of $\mathrm{pH}$ allow biochar-incorporated soils to resist the variation in $\mathrm{pH}$ and to increase their buffering capacity for longer periods [44].

The $\mathrm{pH}$ value of biochar is generally varying from 5.9 to 12.3 , with an average of 8.9 [29]. The biochar $\mathrm{pH}$ value depends strongly on the pyrolysis temperature. With the increase in temperature $\left(>350{ }^{\circ} \mathrm{C}\right)$, alkali salts start to separate from organic materials and basic cations increase in biochars, which increases the biochar $\mathrm{pH}$ [45]. In contrast, at low pyrolysis temperatures $\left(200-300{ }^{\circ} \mathrm{C}\right)$, acidic biochar is produced due to the decomposition of cellulose and hemicelluloses, which yields organic acids [46]. In addition to $\mathrm{pH}$ and CEC, the elemental composition and the atomic ratios of $\mathrm{H} / \mathrm{C}$ and $\mathrm{O} / \mathrm{C}$ are the main chemical properties of biochar. Biochar is determined by its stable $\mathrm{C}$ existing in the inorganic phase in the form of carbonate and bicarbonate, and in the organic phase as aliphatic carbon, aromatic carbon, and functionalized carbon [32,43]. The elemental composition of biochar is constituted by major elements $(\mathrm{C}, \mathrm{H}, \mathrm{O}$, and $\mathrm{N}$ ) and other elements $(\mathrm{P}, \mathrm{S}, \mathrm{Si}, \mathrm{Cu}, \mathrm{Fe}, \mathrm{Zn}$, and $\mathrm{Mn}$ ) present in variable percentages depending on the nature of feedstock and the pyrolysis conditions $[47,48]$. These elements make the surface of the biochar heterogeneous and reactive $[49,50]$. Higher pyrolysis temperatures intensified polymerization reactions and reduced the atomic ratios of $\mathrm{H} / \mathrm{C}$ and $\mathrm{O} / \mathrm{C}[38,48]$. Biochars typically have a lower molar $\mathrm{H} / \mathrm{C}$ ratio than that of feedstocks [51,52], indicating a high content of aromatic structures and a potential recalcitrance of the biochar. The $\mathrm{N}$ in biomass is generally present in the form of proteins, amino acid, pyrrolic, and pyridine. Peptide- $\mathrm{N}$ bonds transform during pyrolysis into $\mathrm{N}$-heteroaromatic carbon compounds, and some amide- $\mathrm{N}$ reduces at elevated pyrolysis temperature. Organic phosphorus is converted to inorganic form, which is not volatilized at a pyrolysis temperature below $700{ }^{\circ} \mathrm{C}$. The phosphorus content is enriched within the biochar and could serve as a source of phosphorus for the plant [53]. Generally, the content of phosphorus, as well as that of other elements such as $\mathrm{Ca}, \mathrm{Mg}, \mathrm{K}$, $\mathrm{Fe}, \mathrm{Si}, \mathrm{S}, \mathrm{Zn}, \mathrm{Cu}$, and $\mathrm{Mn}$, increases as the pyrolysis temperature increases; however, these elements' bioavailability is reduced due to their insertion into highly aromatic structures within biochar. Contrary to this, at lower pyrolysis temperatures, an improvement in the bioavailability of these nutrients is observed. Naeem et al. [54] showed that exchangeable $\mathrm{K}$ in maize straw-derived biochars produced at 300 and $400{ }^{\circ} \mathrm{C}$ was more available to plant roots than that in biochars pyrolyzed at $500{ }^{\circ} \mathrm{C}$. In addition to pyrolysis temperature, the nature of feedstock also affects the chemical properties of biochar. For instance, biochars derived from wood-based biomass are reported to be more resistant to biodegradation than biochars obtained from crop residues and animal manures [27,55]. Contrary to this, biochar produced from manure contains more nutrients [56,57]. Elemental composition and some other characteristics of biochar derived from different feedstocks and at different pyrolysis temperatures are listed in Table 1 . The main properties of biochar and various forms of its application in agriculture are summarized in Figure 1. 
Table 1. Change in biochar characteristics as a result of different pyrolysis temperatures and types of feedstock.

\begin{tabular}{|c|c|c|c|c|c|c|c|c|c|c|c|c|c|}
\hline \multirow{2}{*}{ Feedstock/Pyrolysis Temperature } & \multicolumn{7}{|c|}{ Characteristics } & \multirow[b]{2}{*}{$\mathrm{K}[\%]$} & \multirow[b]{2}{*}{$\mathrm{C} / \mathrm{N}$} & \multirow[b]{2}{*}{$\mathrm{O} / \mathrm{C}$} & \multirow[b]{2}{*}{$\mathrm{H} / \mathrm{C}$} & \multirow[b]{2}{*}{$\mathrm{CEC}[\mathrm{cmol} / \mathrm{kg}]$} & \multirow{2}{*}{ Ref. } \\
\hline & $\mathrm{S}_{\mathrm{BET}}\left[\mathrm{m}^{2} / \mathrm{g}\right]$ & Ash [\%] & $\mathrm{pH}$ & $\mathrm{C}[\%]$ & $\mathbf{N}[\%]$ & H [\%] & $\mathbf{P}[\%]$ & & & & & & \\
\hline Shrimp hull $/ 500{ }^{\circ} \mathrm{C}$ & 13.3 & 83.5 & 10.3 & - & - & - & 2.585 & 1.896 & - & - & - & 389 & [58] \\
\hline Oak wood $/ 200^{\circ} \mathrm{C}$ & - & - & 4.6 & 48.8 & 0.2 & - & 0.03 & 0.13 & 257 & - & - & 54.2 & [45] \\
\hline Oak wood $/ 600^{\circ} \mathrm{C}$ & - & - & 9.5 & 45.5 & 0.4 & - & 0.06 & 0.44 & 111 & - & - & 97.0 & [45] \\
\hline Wheat straw $/ 250^{\circ} \mathrm{C}$ & - & - & - & 55.57 & 0.98 & - & 0.01 & 1.51 & 57 & - & - & 68.7 & [59] \\
\hline Wheat straw $/ 350^{\circ} \mathrm{C}$ & - & - & - & 58.4 & 1.03 & - & 0.03 & 2.12 & 57 & - & - & 58.6 & [59] \\
\hline Wheat straw $/ 600^{\circ} \mathrm{C}$ & - & - & - & 66.65 & 1.06 & - & 0.02 & 2.02 & 63 & - & - & 40.5 & [59] \\
\hline Wheat straw $/ 500^{\circ} \mathrm{C}$ & - & - & - & 69.18 & 1.02 & - & 0.01 & 2.1 & 68 & - & - & 22.0 & [59] \\
\hline Wheat straw $/ 500^{\circ} \mathrm{C}$ & 111 & 11 & 8.3 & 70.3 & 1.4 & 2.9 & - & - & 57.8 & 0.38 & 0.49 & 5.1 & [60] \\
\hline Wheat-straw $/ 600^{\circ} \mathrm{C}$ & 177 & 12 & 9.2 & 73.4 & 1.4 & 2.1 & - & - & 62.0 & 0.31 & 0.35 & 1.3 & [60] \\
\hline Corn stover $/ 300^{\circ} \mathrm{C}$ & 3.19 & 5.7 & 7.7 & 45.5 & 0.63 & 5.4 & - & - & & & & & [61] \\
\hline Corn stover $/ 400^{\circ} \mathrm{C}$ & 3.17 & 12.5 & 8.8 & 64 & 0.42 & 3.9 & - & - & - & - & - & - & [61] \\
\hline Corn stover $/ 500^{\circ} \mathrm{C}$ & 4.58 & 18.7 & 9.8 & 64.5 & 0.25 & 2.7 & - & - & - & - & - & - & [61] \\
\hline Rice husk $/ 300^{\circ} \mathrm{C}$ & - & 21.8 & 6.8 & - & - & - & - & - & - & - & - & - & [62] \\
\hline Rice husk $/ 500^{\circ} \mathrm{C}$ & - & 32.8 & 10.4 & - & - & - & - & - & - & - & - & - & [62] \\
\hline Rice husk $/ 700^{\circ} \mathrm{C}$ & - & 35.6 & 10.7 & - & - & - & - & - & - & - & - & - & {$[62]$} \\
\hline Sugarcane bagasse $/ 350^{\circ} \mathrm{C}$ & - & 11.0 & 7.8 & - & - & - & - & - & - & - & - & - & [62] \\
\hline Sugarcane bagasse $/ 500^{\circ} \mathrm{C}$ & - & 11.5 & 9.2 & - & - & - & - & - & - & - & - & - & [62] \\
\hline Eucalyptus sawdust $/ 450{ }^{\circ} \mathrm{C}$ & - & 0.7 & - & 78.6 & - & 3.42 & - & - & - & 0.16 & 0.52 & - & [63] \\
\hline Eucalyptus sawdust $/ 750^{\circ} \mathrm{C}$ & - & 1.1 & - & 90.9 & - & 1.52 & - & - & - & 0.05 & 0.20 & - & [63] \\
\hline Chicken manure $/ 350^{\circ} \mathrm{C}$ & - & 52.0 & - & 31.2 & - & 1.97 & - & - & - & 0.26 & 0.76 & - & [63] \\
\hline Chicken manure $/ 450^{\circ} \mathrm{C}$ & - & 55.3 & - & 27.2 & - & 1.92 & - & - & - & 0.31 & 0.85 & - & [63] \\
\hline Chicken manure $/ 750^{\circ} \mathrm{C}$ & - & 56.4 & - & 24.7 & - & 0.67 & - & - & - & 0.49 & 0.32 & - & [63] \\
\hline Apple tree branches $/ 300^{\circ} \mathrm{C}$ & 2.39 & 6.72 & - & 62.20 & 1.69 & 5.18 & 0.21 & 0.57 & - & - & - & - & [64] \\
\hline Apple tree branches $/ 400^{\circ} \mathrm{C}$ & - & 7.85 & - & 71.13 & 1.94 & 4.03 & 0.28 & 0.89 & - & - & - & - & [64] \\
\hline Apple tree branches $/ 500^{\circ} \mathrm{C}$ & - & 10.06 & - & 74.88 & 1.77 & 2.88 & 0.34 & 1.10 & - & - & - & - & [64] \\
\hline Apple tree branches $/ 600^{\circ} \mathrm{C}$ & 108.59 & 9.40 & - & 80.01 & 1.28 & 2.72 & 0.34 & 1.14 & - & - & - & - & [64] \\
\hline Corn straw $/ 300^{\circ} \mathrm{C}$ & - & - & 8.51 & 58.79 & 2.2 & 4.16 & - & - & 27 & - & 0.85 & - & [65] \\
\hline Corn straw $/ 450^{\circ} \mathrm{C}$ & - & - & 10.3 & 60.75 & 2.07 & 3.27 & - & - & 29 & - & 0.65 & - & [65] \\
\hline Corn straw $/ 600^{\circ} \mathrm{C}$ & - & - & 10.9 & 63.65 & 2.04 & 2.51 & - & - & 31 & - & 0.47 & - & [65] \\
\hline Composted swine manure $/ 700^{\circ} \mathrm{C}$ & 116.9 & 61.72 & 10.78 & 34.92 & 1.09 & 0.58 & - & - & - & 0.04 & 0.20 & - & [66] \\
\hline Miscanthus sacchariflorus $/ 600^{\circ} \mathrm{C}$ & 381.5 & 2.25 & 10.05 & 90.71 & 0.33 & 2.26 & - & - & - & 0.06 & 0.30 & - & [67] \\
\hline
\end{tabular}

$\mathrm{S}_{\mathrm{BET}}$ : Brunauer-Emmett-Teller (BET) surface area. 


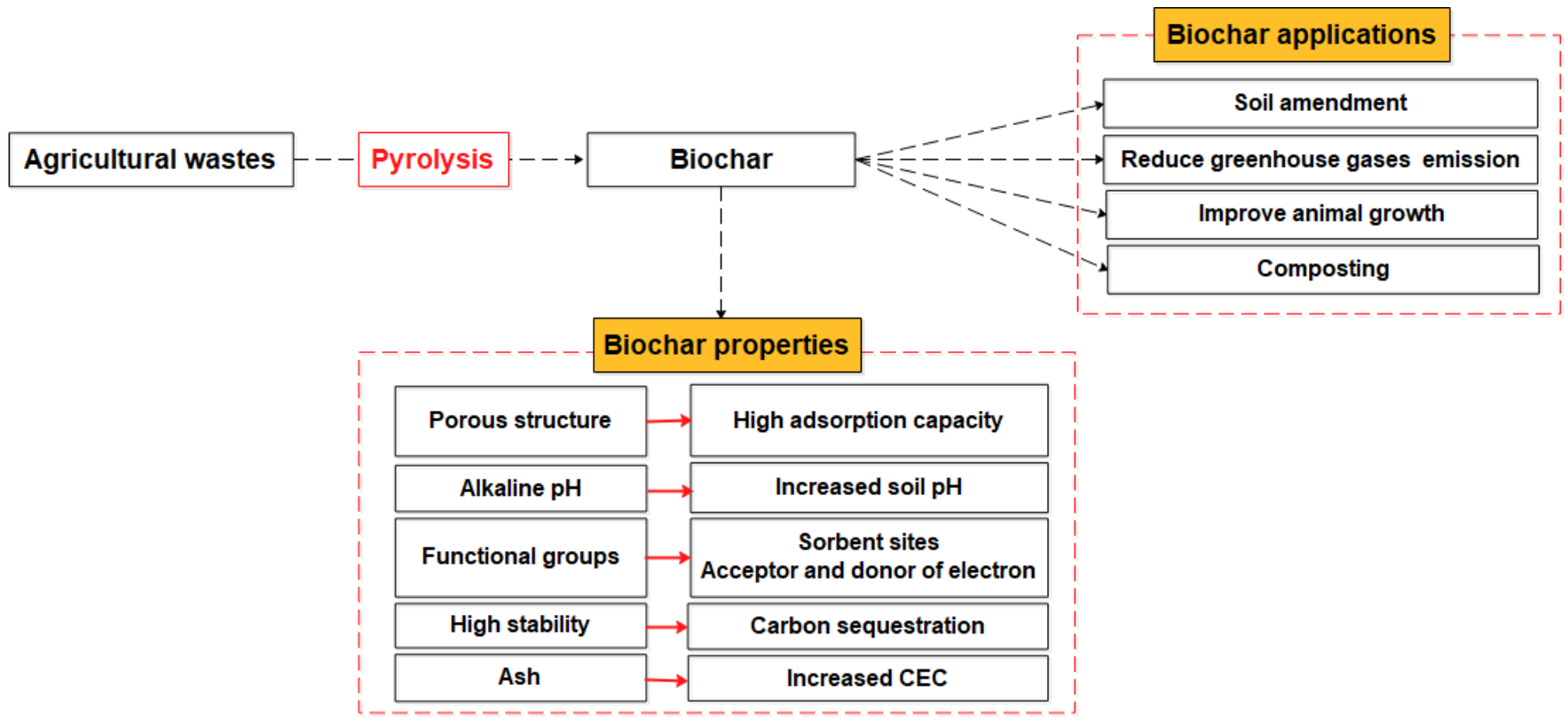

Figure 1. Overview of biochar properties and different forms of its agricultural application.

\section{Biochar as a Soil Amendment}

\subsection{Impacts on Soil Structure and Composition}

Biochar has been described as an attractive material that can be applied in agriculture to improve agricultural soil properties and crop productivity. The main impacts of biochar on soil characteristics and agricultural products yield are listed in Table 2 and Figure 2.

Table 2. Influence of biochar application on soil properties and agricultural product yield.

\begin{tabular}{|c|c|c|c|c|c|}
\hline $\begin{array}{l}\text { Biochar } \\
\text { Feedstock }\end{array}$ & Application Rate & Plant & $\begin{array}{l}\text { Effects on Soil } \\
\text { Properties }\end{array}$ & Effects on Crops & Ref. \\
\hline $\begin{array}{l}\text { Orchard prune } \\
\text { residues }\end{array}$ & - & Tomato & $\begin{array}{l}\text { Increase in soil } \mathrm{pH} \text { and } \\
\text { pore water }\end{array}$ & $\begin{array}{l}\text { Increase in fresh biomass } \\
\text { by } 43 \% \text { and dry biomass } \\
\text { by } 5 \%\end{array}$ & [68] \\
\hline Straw & $\begin{array}{l}0,20,40, \text { and } 60 \mathrm{~g} \\
\text { biochar } / \\
\text { kg soil }\end{array}$ & - & $\begin{array}{c}\text { Enhancement in } \\
\text { aggregate stability } \\
\text { Increase in the available } \\
\text { water contents of soils }\end{array}$ & - & [69] \\
\hline Maize stalk & - & Zucchini & $\begin{array}{l}\text { Increase in soil organic } \\
\text { matter }\end{array}$ & $\begin{array}{l}\text { Increase in fruit yield by } \\
\qquad 27-195 \%\end{array}$ & {$[70]$} \\
\hline Peanut shell & - & Lettuce & $\begin{array}{l}\text { Increase in soil } \mathrm{pH} \text { and } \\
\text { soil organic matter }\end{array}$ & $\begin{array}{l}\text { No significant effect on } \\
\text { vegetable yield }\end{array}$ & [71] \\
\hline Apple branch & $\begin{array}{c}0,0.5 \%, 1 \%, 2 \% \\
\text { and } 4 \%\end{array}$ & Crabapple & $\begin{array}{c}\text { Decrease in soil nitrate } \\
\text { leaching }\end{array}$ & $\begin{array}{c}\text { Increase in biomass and N } \\
\text { use efficiency }\end{array}$ & {$[72]$} \\
\hline- & $5 \mathrm{~kg} /$ tree & Apple & - & $\begin{array}{c}\text { Crop yield and fruit } \\
\text { quality did not show any } \\
\text { improvement } \\
\text { Trunk girth significantly } \\
\text { improved as compared to } \\
\text { the control }\end{array}$ & [73] \\
\hline
\end{tabular}


Table 2. Cont.

\begin{tabular}{|c|c|c|c|c|c|}
\hline $\begin{array}{c}\text { Biochar } \\
\text { Feedstock }\end{array}$ & Application Rate & Plant & $\begin{array}{l}\text { Effects on Soil } \\
\text { Properties }\end{array}$ & Effects on Crops & Ref. \\
\hline Bamboo branch & $0,5,10,20 \mathrm{t} / \mathrm{ha}$ & Bamboo & $\begin{array}{c}\text { Increase in soil moisture, } \\
\text { soil microbial biomass } \\
\text { and influence on the } \\
\text { mean soil respiration } \\
\text { rate }\end{array}$ & - & {$[74]$} \\
\hline $\begin{array}{c}\text { Olive stone, } \\
\text { almond shell, } \\
\text { wheat straw, pine } \\
\text { woodchips, and } \\
\text { olive-tree pruning }\end{array}$ & $0.5-7.5 \%(w / w)$ & Sunflower & $\begin{array}{l}\text { Decrease in soil bulk } \\
\text { density and increase in } \\
\text { soil field capacity } \\
\text { Increase in dissolved } \\
\text { organic C, available P } \\
\text { and decrease in soil } \\
\text { nitrate concentration }\end{array}$ & $\begin{array}{l}\text { Increase in seed } \\
\text { germination, plant dry } \\
\text { biomass and crop } \\
\text { production }\end{array}$ & [75] \\
\hline Poultry waste & $0-1 \%(w / w)$ & Brassicacampestris & $\begin{array}{l}\text { Improvement in soil } \\
\text { physical and chemical } \\
\text { conditions } \\
\text { Enhancement of the } \\
\text { availability of nutrients } \\
\text { especially nitrogen }\end{array}$ & $\begin{array}{l}\text { Decrease in metals uptake } \\
\text { in Brassica campestris and } \\
\text { improvement of growth } \\
\text { Increase in photosynthetic } \\
\text { and accessory pigments } \\
\text { production }\end{array}$ & [76] \\
\hline $\begin{array}{l}\text { Hardwood and } \\
\text { softwood }\end{array}$ & $0-5 \%(w / w)$ & Potato & - & $\begin{array}{c}\text { Mitigation of salinity } \\
\text { stress } \\
\text { Increase in shoot biomass, } \\
\text { root length and volume, } \\
\text { tuber yield, } \\
\text { photosynthetic rate, } \\
\text { midday leaf water } \\
\text { potential, and increase in } \\
\mathrm{K}^{+} \text {content in xylem }\end{array}$ & [77] \\
\hline Corn cob & $10-20 \mathrm{t} / \mathrm{ha}$ & Soybean & - & $\begin{array}{l}\text { Mitigation of water stress } \\
\text { effects on soybean } \\
\text { seedling especially at an } \\
\text { application rate of } 20 \mathrm{t} / \mathrm{ha} \\
\text { Enhancement in seedling } \\
\text { growth } \\
\text { Mitigation drought stress } \\
\text { impacts } \\
\text { Improvement in } \\
\text { germination rate, shoot } \\
\text { length and chlorophyll } \\
\text { and carotenoid contents }\end{array}$ & [78] \\
\hline Virgin pine wood & $30 \mathrm{t} / \mathrm{ha}$ & Maize & $\begin{array}{l}\text { No effect on the soil food } \\
\text { web because the soil } \\
\text { biological community is } \\
\text { already degraded }\end{array}$ & - & [79] \\
\hline
\end{tabular}


Table 2. Cont.

\begin{tabular}{|c|c|c|c|c|c|}
\hline $\begin{array}{l}\text { Biochar } \\
\text { Feedstock }\end{array}$ & Application Rate & Plant & Effects on Soil Properties & Effects on Crops & Ref. \\
\hline Wheat & $12 \mathrm{t} / \mathrm{ha}$ & Maize & $\begin{array}{l}\text { Significant decrease in soil } \\
\text { salinity }\end{array}$ & $\begin{array}{l}\text { Mitigation of salinity stress } \\
\text { and improvement in maize } \\
\text { grain yield and plant } \\
\text { performance in saline } \\
\text { croplands } \\
\text { Increase in maize leaf sap } \\
\text { nitrogen, phosphorus and } \\
\text { potassium and decrease in } \\
\text { sodium and chloride } \\
\text { Improvement in leaf } \\
\text { bioactivity related to } \\
\text { osmotic stress }\end{array}$ & [80] \\
\hline $\begin{array}{c}\text { Pellets of } \\
\text { coniferous wood }\end{array}$ & $\begin{array}{c}0 \text { or } 5 \% \\
(v / v)\end{array}$ & Lettuce & $\begin{array}{l}\text { Reduced conductivity in } \\
\text { biochar-ameliorated soils }\end{array}$ & $\begin{array}{l}\text { Reduced Na uptake of } \\
\text { plants }\end{array}$ & [81] \\
\hline Rice straw & $22.5 \mathrm{t} / \mathrm{ha}$ & Rice & $\begin{array}{c}\text {-Increase in total } \mathrm{C} \text { and } \\
\text { total } \mathrm{N} \text { contents } \\
\text {-Increase in } \mathrm{C} / \mathrm{N} \text { ratio and } \\
\text { moisture of rhizosphere } \\
\text { soil } \\
\text {-Increase in soil pH and } \\
\text { water retention ability }\end{array}$ & $\begin{array}{l}\text { Enhancement in rice yield } \\
\text { and } \mathrm{N} \text { retention in a paddy } \\
\text { field }\end{array}$ & [82] \\
\hline Poultry manure & $1 \%(w / w)$ & Barley & $\begin{array}{l}\text {-Improvement in } \\
\text { petroleumhydrocarbons- } \\
\text { degradation } \\
\text {-Improvement in } \\
\text { soilmicrobial respiration }\end{array}$ & Increase in dry weight yield & [83] \\
\hline Maize stubble & $3 \%$ & Maize & - & $\begin{array}{l}\text { Improvement in chlorophyll } \\
\text { content and shoot to root } \\
\text { biomass } \\
\text { Decrease in contaminant } \\
\text { retention by shoots }\end{array}$ & [84] \\
\hline
\end{tabular}

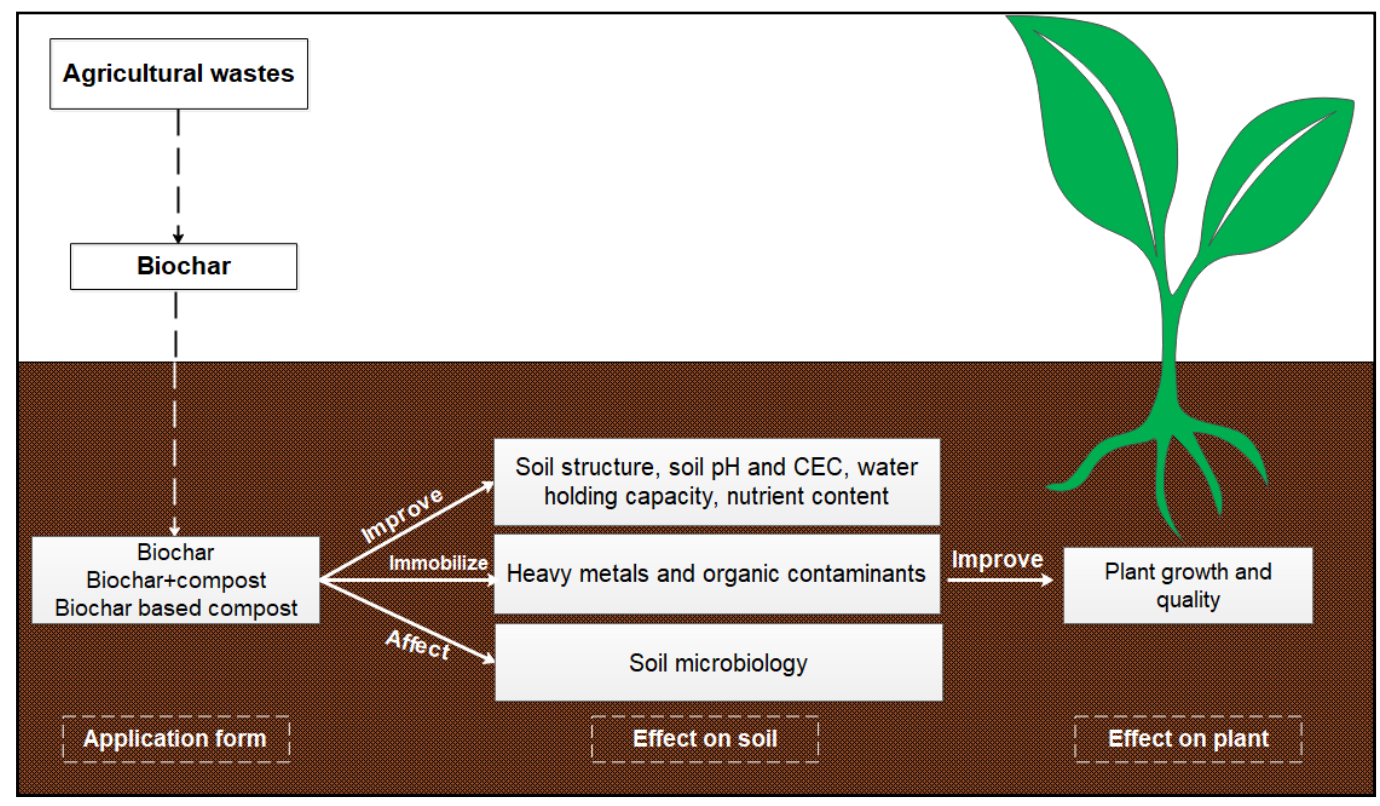

Figure 2. Benefits of biochar amendment for soil and plant production. 
Biochar improves the soil texture and porosity, increases the $\mathrm{pH}$ buffering capacity of soils, increases CEC and helps in the binding of important anions and cations [85]. The increase in the soil $\mathrm{pH}$ subsequent to the addition of biochar improves the retention of basic cations in acid tropical soils and consequently improves the crop nutrition [86]. Similarly, Atkinson et al. [87] confirmed that the increase in the soil $\mathrm{pH}$ following biochar addition enhances the availability of phosphorous and potassium. Alkaline biochars are more suitable for acidic soils [88], while low-pHbiochars could be effectively applied to alkaline soils to lower their $\mathrm{pH}$ [89]. The soil CEC increases after biochar addition due to the enhancement of the oxidation of aromatic carbon [90]. The increase in CEC helps in improving nutrients retention in the soil and in mitigating leaching process, which increases the fertility of the soil [91]. The physico-chemical properties of soils in humid areas of Asia varied significantly following biochar addition, where $\mathrm{pH}$ value increased from 3.9 to 5.1, CEC from 7.41 to $10.8 \mathrm{cmol} / \mathrm{kg}$, base cation percentage from 6.4 to 26 , and bulk density decreased from 1.4 to $1.1 \mathrm{mg} / \mathrm{m}^{3}$ [92]. In a study performed by Huang et al. [93], authors recorded an increase in the key indicators of soil quality by about $33 \%$ for soil organic carbon, $6 \%$ for $\mathrm{pH}, 10 \%$ for total nitrogen and $43 \%$ for $\mathrm{N}$-use efficiency. Application of biochar also promoted the formation of macro aggregates in soils, which decreased the soil erosion potential [92]. Soils behave differently following biochar addition. Despite the good number of studies reporting the positive impact of biochar addition on fertility of tropical and subtropical soils and plant growth and yield [86,94], other investigations showed that the improvements in crop production were only observed in highly degraded and nutrient-poor soils [95], while richer soils showed less tendency to take benefits from biochar addition. Nevertheless, soil amendment with biochar is still an effective method for $C$ sequestration in soils [73]. In addition to biochar properties, soil type and composition and the method of biochar application, i.e., single application of biochar or combined application with compost, are essential factors that define the effects of biochar on soil agronomic properties.

Despite the favorable effect of biochar on soil properties, some noticeable unfavorable changes in soil structure and composition following the addition of biochar have also been reported. Mukherjee et al. [96] applied oak-derived biochar pyrolyzed at $650{ }^{\circ} \mathrm{C}$ to silt loam soil in a field experiment of 16 weeks and observed that the resistance to water penetration in soil was lowered by $10-18 \%$. Authors reported that short-term application of biochar could not lead to a significant effect on the physico-chemical properties of soils, whereas greater changes are mainly related to biochar ageing. Moreover, biochar in certain cases may contain some potential contaminants such as $\mathrm{Zn}, \mathrm{Cu}, \mathrm{Cd}, \mathrm{Pb}$ and $\mathrm{Cr}$ when prepared from toxic solid wastes [97]; this can lead to undesirable effects on soil composition and soil microbial activity.

\subsection{Impacts on Water Retention}

Many investigations reported that biochar amendment improves soil water retention capacity [98-100] and reduces the water stress of plants during prolonged dry periods caused by global climate changes in the future [101-104]. The highly porous structure of biochar improves soil physical properties and interstitial spaces within the biochar-soil matrix and allows the reorganization of pore size distribution, which enhances the soil's water retention capacity $[24,69]$. Biochar has a hydrophilic surface because of the presence of oxygen-containing functional groups on its surfaces [105], which enables water to infiltrate into its intrapores [106]. An increase in the number of oxygen-containing functional groups on the biochar surfaces induces an enhancement ofthe biochar's hydrophilicity [105]. Another consideration that must be examined during biochar amendment is its effect on plant-available water content. Generally, biochar improves plant-available water, but the improvement significance is quite dependent on soil texture; the water uptake by plants increase by $45 \%$ for coarse-textured soils, by $21 \%$ for the medium-textured soils, and by only $14 \%$ for fine-textured soils, while others reported different values between 4 and $130 \%$ [26] and an average of $15 \%$ [107]. Although a high number of investigations reported 
the beneficial effect of biochar on water content in soils, other studies reported contrary results. Jeffery et al. [108] applied biochar produced from herbaceous plant cuttings to a sandy soil at a rate of 1-50 $t /$ ha and reported no significant enhancement in soil water retention ability, even with the increase in its porosity following biochar addition. The authors attributed that to the high hydrophobicity of biochar, which allowed for preventing the infiltration of water into soil intrapores and then negatively affected its water retention ability. Additionally, not all studies reported the favorable effect of biochar addition on plant growth and yield. In the work performed by Herath et al. [109], the application of biochar derived from maize stover at a rate of $11.3 \mathrm{Mg} / \mathrm{ha}$ for 295 days resulted in no effect on available water capacity; this tendency is probably associated with the blockage of soil micropores by some components contained in the applied biochar, such as ash.

\subsection{Impacts on Nutrients Availability}

Biochar can incorporate many macronutrients and micronutrients into soil that can be used by plants [110]. The amount of incorporated carbon, which will be used by microbial communities or sequestered in soil, depends strongly on pyrolysis temperature and therefore varies from biochar to biochar. During pyrolysis and depending on carbonization temperature, some elements, such as $\mathrm{C}, \mathrm{N}, \mathrm{H}, \mathrm{O}$ and $\mathrm{S}$, are partly lost in the form of volatile substances, while other elements, including $\mathrm{P}$ and $\mathrm{K}$ and other metals, are more concentrated in the biochar than in the feedstock, which increases the fertility of soil [111-113]. Many investigations reported that biochar-amended soil has a high ability to capture ammonium and nitrate [113,114], and to prevent nitrate leaching [115-117]. Wang et al. [118] showed that biochar amendment significantly increased rice $\mathrm{N}$-uptake and reduced leaching of $\mathrm{N}$-forms from the soil.

The effect of biochar on the concentration of $\mathrm{N}$-forms in soils depends on many factors, including the pyrolysis temperature, the residence time of biochar in soil, the biochar application rate and the soil $\mathrm{pH}$ [119]. Nguyen et al. [119] showed that the concentrations of ammonium and nitrate are reduced following biochar amendment by about $-11 \%$ and $-10 \%$, respectively. The significance of reduction depends, according to the authors, on the residence time of biochar in the soil, and decreases as the biochar ages. Comparably, Liu et al. [120] reported that nitrate concentration decreased by $12 \%$ after biochar application. By contrast, Borchard et al. [121] observed an averaged decrease in nitrate leaching by $-13 \%$ and $\mathrm{N}_{2} \mathrm{O}$ emissions by $-38 \%$ in the majority of biochars that were applied to soils. This reduction is, however, dependent on the soil type and the residence time of biochar in the soil. Similarly, Hagemann et al. [113] reported that biochars could prevent nitrate loss from agro-ecosystems and act as a slow-release fertilizer, which can reduce global $\mathrm{N}$ fertilizer demands. Following biochar addition, not only $\mathrm{N}$ but also $\mathrm{P}$ leaching is reduced. According to Liang et al. [122], the conversion of manure into biochar allows the formation of less soluble $(\mathrm{Ca}, \mathrm{Mg})_{3}\left(\mathrm{PO}_{4}\right)_{2}$, which is preserved in the biochar produced. Similarly, Hong and $\mathrm{Lu}$ [123] observed an enhancement of $\mathrm{P}$ availability in soil after biochar addition, which may help in reducing the demand for chemical fertilizers in biochar-amended soils.

\subsection{Impacts on Soil Microbiology and Enzymes}

Soil microbial populations play a primordial role in the decomposition of organic substances, in nitrogen fixation and in nutrient cycling. In many investigations, biochar application to soil has been proven to increase microbial biomass and to affect nutrient cycling, enzyme activities and crops health [124].

Soil microbial populations are affected, as biochar has an influence on soil chemical and physical properties including $\mathrm{pH}$, nutrient availability, and water retention capacity [125]. Biochar provides space for colonization, forms habitats for different microorganisms [126], and potentially protects them from desiccation and predation. Biochar amendment is accompanied by a general change in the use of carbon sources and can therefore lead to substantial changes in the microbial functional diversity and activity and in the taxonomical composition of the microbial community [127]. Liao et al. [128] recorded in a 
maize/legume intercropping system that biochar addition not only affectedthe bacterial community structure and the diversity of the rhizosphere, but also made plant-derived C assimilable to more microbial species following biochar addition. Li et al. [129] reported an increase in the bacterial abundance by about $161 \%$ when straw- and wood-derived biochars were applied to soil; this increase was especially remarkable for Gram-positive bacteria. In a study performed by Han et al. [130], among 45 bacterial genera, 21 genera were affected by biochar in cotton soils. The results show an increase in the abundance of Sphingomonas and Pseudomonas genera, while the abundance of nitrite-oxidizing bacteria was reduced [130]. Nitrospira is one of the nitrite-oxidizing bacteria, which is, in addition to other contributors in the $\mathrm{N}$ cycle, reported to be influenced by biochar application [131]. Li et al. [132] observed at a rate of $4 \%$ biochar addition an increase in the diversity of genes (nirK and nirS) related to denitrifying bacteria. Rafique et al. [133] observed that biochar in the presence of phosphate-solubilizing bacterium Lysinibacillusfusiformi can also improve the retention of phosphorous and nitrogen by maize plants by about $61.5 \%$ and $23.1 \%$, respectively. Biochar was also proved for its ability to suppress soil pathogens and diseases. Elad et al. [134] observed a significant decrease in the intensity of the disease caused by foliar fungal pathogens in pepper and tomato upon biochar application. Similarly, Harel et al. [135] obtained results for strawberries. Jaiswal et al. [127] reported that biochar allowed the suppression of Fusarium crown and tomato root-rot, which leads simultaneously to an improvement in tomato plant growth. In another study, Huang et al. [136] showed that biochar decreases the sensitivity of rice plants to root knot nematode infections. Biochar has been also reported to enhance plant defense systems against fungi and to significantly reduce the colonization of roots by arbuscular mycorrhiza fungus [137] and to suppress the infection of tomato plants by Fusarium oxysporumf.sp. lycopersici [138]. Although a high number of studies have examined the impact of biochar on the microbial population in the soil, some points nevertheless need to be investigated. The interrelation of soil microorganisms with biochar and the special scale of this interaction have to be studied. The long-term impact of biochar and biochar ageing on soil microorganisms should be further clarified to prevent any possible negative impact. The large-scale study of the biochar impact on the microbial population of the soil under field conditions is still missing [139].Enzymes in the soil play a crucial role in decomposing organic substances and make both energy and $\mathrm{NH}_{4}$ available to plants. Since biochar application stimulates changes in soil structure and composition, the production of enzymes by microbial communities will also change; the production of some enzymes will increase, while others will decrease [125]. Luo and Gu [140] claimed that biochar amendments in mangrove sediments induced an increase in enzymes such as phenol oxidase and $\beta$-glucosidase, while other enzymes such as peroxidase, $\mathrm{N}$-acetyl-glucosaminidase, and acid phosphatase decreased. The influence of biochar on the activity of soil enzymes can vary. This depends on the soil type and the presence of substances that interact with biochar and can thus make it inaccessible to soil enzymes [141]. As compared to activated carbon exhibiting much higher surface area, biochar amendments may preserve most of enzyme'sactivity when adsorbed on its surface due to substrate availability [125]. The effect of biochar application on soil enzyme composition has been proven; however, the mechanisms controlling biochar interactions with enzymes and the response of each enzyme in soil to biochar application still have to be clarified in further investigations.

\subsection{Impacts of Biochar on Plant Growth}

Biochar addition stimulates soil fertility and then improves seed germination and crop productivity. Uzoma et al. [142] recorded an increase in maize grain yield by about $98 \%$ at biochar application rates of 15 and $20 \mathrm{t} / \mathrm{ha}$. Similarly, an increase of 12 to $14 \%$ was observed in rice yield in a paddy rice soil in China after the addition of biochar at application rates of 10 and $40 \mathrm{t} / \mathrm{ha}$ without fertilizer addition [91]. Houben et al. [143] reported a three-fold increase in biomass production of rapeseed crop in a heavy metal-contaminated soil after $10 \%$ biochar addition. Hossain et al. [144] reported an increase in cherry tomato yield by 
about $64 \%$ during a pot experiment, with simultaneous enhancement in $\mathrm{P}$ and $\mathrm{K}$ uptake and soil chemical properties. An increase in $\mathrm{pH}, \mathrm{N}, \mathrm{P}, \mathrm{K}, \mathrm{Ca}$ and $\mathrm{Mg}$ concentrations in a low-organic carbon and -fertility soil in the southeastern United States was observed by Gaskin et al. [145] after addition of peanut hull biochar. In the same study, authors recorded a simultaneous significant response of corn yield following biochar application during the experiment lasting for two-year. The depth of roots and the existence of biochar in the root zone play a primordial role in defining the influence of biochar addition on plant growth. Jones et al. [146] reported that a deep rooting of more than $1 \mathrm{~m}$ is responsible for the insignificant productivity of maize as compared to pasture grass crop characterized by shallow rooting zones $(<30 \mathrm{~cm})$.

Although biochar has been shown to have a positive effect on soil, this cannot always be confirmed for plant growth and yield [98]. Chan et al. [147] reported an increase in radish dry matter after the addition of both biochar and nitrogen fertilizer, but no increase in yield was observed when biochar was used alone, even at the highest application rate of $100 \mathrm{t} / \mathrm{ha}$. Borchard et al. [148] observed neither a positive nor a negative effect on maize yield after biochar application, and also Xu et al. [149] observed lower biomass yield of Suaeda salsa in saline sodic soil. According to some results in the literature, biochar can act positively on same plant species, while negative or no significant effect can be recorded for other species. Bass et al. [98] observed a reduction of $18 \%$ in banana yield, while no remarkable effect was reported for papaya yield. Hagemann et al. [150] also reported that the application of biochar did not induce any effect on sunflower biomass yield. Similarly, Graber et al. [151] showed that biochar addition can increase the flower and fruit yield of pepper plants, but no simultaneous increase in tomato yield was observed.

\subsection{Impacts of Biochar on Heavy Metals and Chemicals Pollution Remediation 3.6.1. Heavy Metals}

Biochar has been widely reported as an efficient material for the retention of both organic and inorganic contaminants [152]. Biochar's interface with pollutants in the soil can be controlled by many mechanisms. According to the assumptions reported in the literature, electrostatic interaction and precipitation in the case of heavy metals, and surface adsorption, partition and sequestration for organic pollutants are the main potential mechanisms controlling the biochar remediation efficiency $[152,153]$. Eco-toxicology of contaminants in soil is mainly related to their bioavailability and their solubility in water, rather than their concentration [154]. Biochar addition to soil systems may affect the mobility and the bioavailability of metals either by direct interaction between metals and biochar or indirectly by inducing variations in soil properties $[155,156]$.The high variation in the characteristics of biomass used as a feedstock for biochar production and the diverse preparation methods and conditions allow the production of biochars with different characteristics, such as $\mathrm{pH}, \mathrm{CEC}$, organic carbon content, porosity, surface functional groups and specific surface area. Biochars will thus behave differently in the soil matrix, and then its interaction with metals and its impact on metal mobility and bioavailability will vary depending on the biochar nature (Table 3). Beesley et al. [157] studied the retention of inorganic contaminants on hardwood-derived biochar added in some specific sites in the UK in a 60 day-study. The results confirm the efficiency of biochar to reduce the concentration of total and bioavailable $\mathrm{Cd}$ and $\mathrm{Zn}$ in pore water, allowing the remediation of contaminated soil. Similarly, Beesley and Marmiroli [158] described a significant decrease in the concentration of inorganic contaminants (As, Cd, Zn) due to biochar adsorption, which significantly reduces their leachate. Kosseva [159] investigated the effect of biochar added to sandy soil on $\mathrm{Cu}$ toxicity in quinoa plants (Chenopodium quinoa). The author observed the same biomass production for quinoa plants in soil treated by $4 \%$ biochar as in the control with the maximum $\mathrm{Cu}$ concentration. 
Table 3. Removal of heavy metals from soils at different rates of biochar application.

\begin{tabular}{|c|c|c|c|c|}
\hline Feedstock & Contaminants & Application Rate & Removal Efficiency (\%) & Ref. \\
\hline Sugarcane bagasse & $\mathrm{Cd}, \mathrm{Cr}$ & $15 \mathrm{~g} / \mathrm{kg}$ ( $w / w$ basis $)$ & $\begin{array}{l}\text { Decrease in the availability of } \mathrm{Cr}-\text { and } \mathrm{Cd} \text { in } \\
\text { soil by } 85 \text { and } 63 \%\end{array}$ & [160] \\
\hline Palm & $\mathrm{Cd}, \mathrm{As}$ & $\begin{array}{l}0 \text { and } 1.5 \mathrm{t} / \mathrm{ha} / \text { each } \\
\text { season }\end{array}$ & $\begin{array}{l}\text { Decrease in Cd by } 43-67 \% \text { and As by } \\
\qquad 16-33 \%\end{array}$ & [161] \\
\hline Wheat straw & $\mathrm{Cd}, \mathrm{Pb}$ & 0,20 , and $40 \mathrm{t} / \mathrm{ha}$ & $\begin{array}{c}\text { Decrease in } \mathrm{Cd} \text { by } 6-14 \% \text { in years } 1 \text { and } 3 \\
\text { and } \mathrm{Pb} \text { by } 24-67 \% \text {, no significant reduction } \\
\text { at higher biochar application rate }\end{array}$ & [162] \\
\hline Poplar woodchips & $\mathrm{Cd}, \mathrm{Pb}, \mathrm{Zn}$ & $0,1 \%$ & $\begin{array}{l}\text { Decrease in Cd by } 75 \%, \mathrm{~Pb} \text { by } 86 \% \text { and } \mathrm{Zn} \\
\text { by } 92 \%\end{array}$ & [163] \\
\hline $\begin{array}{l}\text { Rape straw and rice } \\
\text { straw }\end{array}$ & $\mathrm{Pb}, \mathrm{Cu}$ & $0,2 \%$ and $5 \%$ & $\begin{array}{l}\text { Reduction in the mobility and } \\
\text { phyto-availability of } \mathrm{Pb} \text { and } \mathrm{Cu} \text { in two years } \\
\text { Decrease in the concentration of } \mathrm{Pb} \text { by } \\
40.81 \% \text { and } \mathrm{Cu} \text { by } 56.14 \% \text { in plant tissues }\end{array}$ & [164] \\
\hline Rice straw & $\mathrm{Cd}$ & $0,10 \mathrm{t} / \mathrm{ha}$ and $20 \mathrm{t} / \mathrm{ha}$ & $\begin{array}{l}\text { Reduction in the Cd concentration by } \\
\qquad 8.6-50.2 \%\end{array}$ & [165] \\
\hline Rice straw & $\mathrm{Cd}$, As & - & $\begin{array}{l}\text { The maximum removal rate of } \mathrm{Cd}(\mathrm{II}) \text { was } \\
98 \% \text { and that of } \mathrm{As}(\mathrm{III}) \text { is } 85 \%\end{array}$ & [166] \\
\hline Sugarcane bagasse & $\mathrm{Cd}, \mathrm{Pb}, \mathrm{Cu}$ & $1.5,2.25$ and $3.0 \mathrm{t} / \mathrm{ha}$ & $\begin{array}{c}\text { Decrease in Cd by } 62-76 \%, \mathrm{~Pb} \text { by } \\
17.3-49.1 \% \text { and } \mathrm{Cu} \text { by } 15-38 \% \text { in shoot }\end{array}$ & [167] \\
\hline Wheat straw & $\mathrm{Cd}$ & 0,20 and $40 \mathrm{t} / \mathrm{ha}$ & $\begin{array}{l}\text { Reduction in rice grain } \mathrm{Cd} \text { by } 61,86 \text { and } \\
57 \% \text { over three seasons } \\
\text { Reduction in available soil Zn by } 35-91 \%\end{array}$ & [168] \\
\hline Sewage sludge & $\begin{array}{l}\text { As, } \mathrm{Cd}, \mathrm{Cu}, \mathrm{Pb} \text { and } \\
\mathrm{Zn}\end{array}$ & $5 \%, 10 \%(w / w)$ & $\begin{array}{c}\text { In comparison to the control PTE: } \\
\text { Reduction in the accumulation in grain of } \\
\text { Asby } 60.2-67.5 \% \text {, of } \mathrm{Cd} \text { by } 26.5-42.0 \% \text { of } \mathrm{Cu} \\
\text { by } 24.0-29.3 \% \text { of } \\
\mathrm{Pb} \text { by } 32.5-37.7 \% \text { and of } \mathrm{Zn} \text { by } 16.6-22.0 \%\end{array}$ & [169] \\
\hline Wheat straw & $\mathrm{Cd}, \mathrm{Pb}$ & $0,10,20,40 \mathrm{t} / \mathrm{ha}$ & $\begin{array}{l}\text { Reduction in } \mathrm{Cd} \text { by } 7.5-23.3 \% \text { and in } \mathrm{Pb} \text { by } \\
\qquad 3.7-19.8 \%\end{array}$ & [170] \\
\hline Wheat straw & $\mathrm{Cd}$ & $782 \mathrm{~kg} / \mathrm{ha}$ & $\begin{array}{l}\text { Reduction in the exchangeable Cd by } 28.6 \% \\
\text { in soil and decrease in the Cd } \\
\text { bioaccumulation factor from } 0.36 \text { to } 0.32\end{array}$ & [171] \\
\hline $\begin{array}{l}\text { Chicken manure, } \\
\text { rape straw }\end{array}$ & $\mathrm{Cd}$ & $\begin{array}{c}1 \%, 5 \%, 10 \%, 15 \% \\
(w / w)\end{array}$ & $\begin{array}{c}\text { Reduction in Cd concentration in soil by } \\
11.64-16.3 \% \text { at an application rate of } 15 \% \\
\text { Reduction in Cd uptake by maize shoots at } \\
\text { application rates of } 1 \% \text { and } 5 \%\end{array}$ & [172] \\
\hline Rice straw & $\mathrm{Cd}$ & $0,10,20 \mathrm{t} / \mathrm{ha}$ & $\begin{array}{l}\text { Cd immobilization in soil increased with } \\
\text { increasing amounts of applied biochar }\end{array}$ & [173] \\
\hline Miscanthus & $\mathrm{Ni}$ & $3,4,5 \%$ & $\begin{array}{l}\text { Reduction in the concentrations of } \mathrm{Ni} \text { in } \\
\text { spinach tissues and in soil with the increase } \\
\text { in biochar rate, however no significant } \\
\text { changes were observed below 3\% rate }\end{array}$ & [174] \\
\hline
\end{tabular}

\subsubsection{Pesticide}

The ability of biochar to lower the bioavailability of pesticides in soils has been widely reported [29,175]. Clay et al. [176] showed that biochar application can significantly increase herbicide sorption but reduce herbicide efficacy. The adsorption of pesticide on biochar mainly depends on the properties of biochar used for remediation. Biochars prepared at higher temperatures present generally higher affinity to adsorb organic pesticide due to electrostatic attraction between organic pollutants and charged surfaces of 
biochars $[29,177,178]$. Another aspect that has to be considered with respect to biochar addition to remediate pesticide in soils is the release of pesticides previously adsorbed onto biochar, which can impact its bioavailability in soils and in surface- and groundwater as well [179]. Thanks to biochar properties, not all adsorbed pesticides can be readily desorbed [179-181]. Khorram et al. [182] showed in a one-step desorption experiment that some amounts of fomesafen adsorbed on soils amended with rice hull biochar at an application rate of $2 \%$ were desorbed; this could be due, according to the authors, to the relatively low surface area of rice hull biochar promoting the detachment of weakly adsorbed molecules of fomesafen molecules from biochar micropores [182]. Deng et al. [183] observed a significant reduction in the bioavailability of atrazine in soil amended with cassava wastes-derived biochar, due to its irreversible chemical binding or sequestration in biochar pores. Wang et al. [184] studied the effect of pyrolysis temperature on the desorption rate of herbicide terbuthylazine in a soil amended with sawdust biochar; the authors showed that the desorption rate is lower and slower in the presence of biochar produced at $700{ }^{\circ} \mathrm{C}$ as compared to that produced at $350{ }^{\circ} \mathrm{C}$. The effect of biochar addition on pesticide sorption-desorption behavior in soils may also be affected by biochar ageing. Zhang et al. [185] showed that biochar ageing decreases biochar's specific surface area, which negatively affects the biochar's sorption capacity. Similarly, Lou et al. [186] reported that ageing of rice straw biochar in soil significantly decreased its sorption capacity to pentachlorophenol. Khorram et al. [187] found that despite the decrease in the sorption capacity of rice hull biochar after 6 months of its application, its ability to sequesterfomesafen is still higher as compared to non-amended soil. In the study performed by Jones et al. [146], the authors showed that the immobilization of triazine pesticides such as simazine varied little as a function of biochar ageing, suggesting the persistent of biochar and its long-term efficiency in soil.

\section{Effect of Biochar on Greenhouse Gas Emissions}

Agricultural activities contribute significantly to the release of greenhouse gases into the atmosphere. Natural processes through photosynthesis can participate in $\mathrm{CO}_{2}$ sequestration; however, the long-term efficiency of this process is limited, as the unstable fraction of $\mathrm{C}$ can be decomposed and returned to the atmosphere as $\mathrm{CO}_{2}$ within months to years [188]. An efficient long-term $C$ sequestration could be only possible by converting biomass into more stable forms of carbon $[188,189]$. Biochar as a carbon material has been widely reported for its high potential for long-term carbon sequestration. The average residence time of biochar in soil can reach thousands of years [190,191]. This is due to its recalcitrant character, which makes its organic fraction unavailable for soil microorganisms and allows for the long-term sequestration of carbon in soils. The results of a life cycle assessment for $\mathrm{CO}_{2}$ sequestration in Miyako Island revealed that if all the available sugarcane bagasse, which is around 12,000 $\mathrm{t}$ /year, is converted to biochar, a total of 1200-1800 $\mathrm{t}$ $\mathrm{CO}_{2}$ can be sequestrated each year [154]. Spokas et al. [192] showed a reduction in $\mathrm{CO}_{2}$ emission in a silt loam soil after the addition of biochar derived from wood chip at a rate of $20 \%(w / w)$. Similar results were also found by Liu et al. [193] in a biochar amended paddy soil. Contrary to this, Major et al. [194] claimed to find an increase in the $\mathrm{CO}_{2}$ emissions after addition of biochar derived from mango (Mangifera indica L.) trees. The same tendency was also reported by Bell and Worrall [195], who observed increased $\mathrm{CO}_{2}$ emissions from unvegetated arable plots amended with lump-wood-derived biochar; however, no significant increase was recorded for planted plots.

Biochar was also reported for its ability to mitigate $\mathrm{CH}_{4}$ and $\mathrm{N}_{2} \mathrm{O}$ emissions from soils [196-198]. The efficiency of biochar in mitigating $\mathrm{CH}_{4}$ and $\mathrm{N}_{2} \mathrm{O}$ emissions is strongly related to soil type, cultivated crops and origin of biochar [124,199].In a 2-year experiment performed by Dong et al. [200], biochar produced from rice straw was reported to be more capable to reduce $\mathrm{CH}_{4}$ emissions from a paddy field than bamboo-derived biochar. The results show a reduction in $\mathrm{CH}_{4}$ emissions of up to $86.43 \%$ during the rice growing cycle and an annual decrease between 20 and $51 \%$ after four years. Similar results were 
also described by Chen et al. [201]. Ibrahim et al. [202] recorded an increase in $\mathrm{CH}_{4}$ emissions with a simultaneous decrease in $\mathrm{CO}_{2}$ release after application of peanut shell and sewage sludge-derived biochars in bean plant growth. Biochar can also affect the denitrification process as reported by Cayuela et al. [203]. The results show a reduction in $\mathrm{N}_{2} \mathrm{O}$ emission by about $10-90 \%$ in 14 different tested soils [203]. Biochar addition promotes the transfer of electrons to denitrifying microorganisms, which accelerates the process of $\mathrm{N}_{2} \mathrm{O}$ reduction. According to Harter et al. [204], the efficiency of biochar in mitigating $\mathrm{N}_{2} \mathrm{O}$ emission is related to its ability in affecting the relative abundance and the taxonomic composition of $\mathrm{N}_{2} \mathrm{O}$-reducing functional microbial in soil. In the study of Brassard et al. [205], biochars with relatively low $\mathrm{N}$ concentrations were reported as being more favorable in reducing $\mathrm{N}_{2} \mathrm{O}$ emissions. In the same line, Harter et al. [206] observed an increase in the transcription of bacterial $\mathrm{N}_{2} \mathrm{O}$ reductase following the addition of biochar in water-saturated soils, with a simultaneous increase in the abundance of $\mathrm{N}_{2}$ fixation bacteria. Many investigations addressed their research to study the impact of biochar on greenhouse gas emissions. The results presented so far are inconsistent, and sometimes biochar is reported as negatively affecting greenhouse gas emissions, depending on the type of biochar and soil properties $[199,207]$. In contrast, several studies have reported positive results, providing sufficient evidence that biochar can effectively reduce greenhouse gas emissions and mitigate climate change [154]. In a field experiment in Australia performed by Scheer et al. [208] with biochar derived from cattle waste, the authors observed no significant changes in greenhouse gas emissions in biochar-amended red Ferrosol soil as compared to the control. In an earlier investigation, Zhang et al. [209] showed that biochar addition to paddy fields in China resulted in positive effects on soil properties and significant reduction in $\mathrm{N}_{2} \mathrm{O}$ emissions, while $\mathrm{CO}_{2}$ remained unchanged and $\mathrm{CH}_{4}$ was only reduced in the second paddy cultivation cycle.

\section{Improving Animal Growth through Biochar}

Scientists and a growing number of farmers conducted experiments where biochar, as non-toxic and edible material, was included into animal farming systems [210]. Since 2010, this practice has begun to be adopted by agricultural practitioners, who found good results in terms of improving productivity. Since 2012, the biochar market in Europe has grown considerably with the use of biochar as an additive to animal feed in Germany and Switzerland [211]. To frame this market, the European Biochar Foundation introduced in 2016 a new certification standard particularly for biochar used in animal feeding [212].

Schmidt et al. [213], in their interesting review, evaluated more than 100 scientific publications on the use of biochar for animal feeding to various animal groups. Most of the reported results were promising and exhibited for all investigated animal groups positive (but not always significant) effects on parameters such as digestion, toxin adsorption, blood values and cell numbers in milk. The authors also claimed the positive effect of biochar on livestock weight gain by increasing the $\mathrm{pH}$, since an alkaline $\mathrm{pH}$ in the rumen could prevent acidosis, which is known to affect livestock weight gain. Similarly, O'Toole et al. [214] and Toth and Dou [215] reported that the oral ingestion of biochar improves animal health by improving nutrient intake and toxins adsorption. Devi et al. [216] reported an enhancement in growth rate of catfish following the addition of biochar at $2 \%$ in animal feed ingredients. Lecroy et al. [217] also recorded an enhancement in piglet growth after dietary biochar powder use as a feed additive.

In other studies, the addition of bamboo biochar enhanced the feed conversion efficiency of flounder [112] and wheat straw-derived biochar reduced abdominal fat deposition and enhanced the growth of poultry [218]. Biochar used as a feed additive can also provide resistance to various diseases and anti-bacterial effects [219] and can enhance the immune function and anti-stress properties of piglets [220]. Despite the large quantity of investigations demonstrating that biochar used as animal fodder has no negative effect, there are still open questions on its long-term impacts, for instance its effect on the resorption of 
liposoluble feed ingredients and potential interaction with themycotoxin fumonisin that should be considered before the unrestricted recommendation of its adoption.

\section{Biochar in Composting}

The mixed use of biochar and compost to soils may significantly affect soil quality and crop productivity [221]. The addition of biochar combined with compost can be performed in two ways: one is that biochar is mixed with compost after the composting process is finished, and the other is that biochar is added to compost at the early stage of the composting process [222]. The first method was reported as enhancing soil nutrient content and crops productivity $[89,223]$, while other authors showed that biochar-based compost is more beneficial for soil and plants. Glaba et al. [224] found that the application of biocharbased compost improves the water retention capacity of sandy soils to a greater extent than compost without biochar. In another study, Kammann et al. [225] described that the application of compost, which is based on biochar, to soils protects nitrate content in biochar from leaching due to ion-water bonding in biochar micro- and nanopores. The addition of biochar during composting allows for improving the properties of the final product due to the biochar porous structure, which increases pile porosity and then enhances $\mathrm{O}_{2}$ supply and avoids anaerobic fermentation [226]. Sánchez-García et al. [227] showed that biochar adjusts the pile density of the compost and prevents the formation of agglomerates larger than $70 \mathrm{~mm}$. Godlewska et al. [228] reported that the use of biochars with alkaline $\mathrm{pHs}$ increases compost $\mathrm{pH}$ value. Contrary to this, Zhang et al. [229] showed that biochar addition to wheat straw and pig manure composts promoted the decomposition of bulk organic matter in the mixture and the release of inorganic and organic acids, which decrease the $\mathrm{pH}$ of the final composts. Biochar addition can also promote the creation of micropores for lactic-acid bacteria, which leads to a decrease in the $\mathrm{pH}$ of the compost [230].

Biochar has been reported to accelerate the humification process during composting [231,232]. Its addition promotes the $C$ transformation from raw materials to humic substances, mainly humicacids, fulvic acids and humans [233]. A compost rich in humic substances can provide a variety of agronomic benefices to soil, including water and nutrients, which enhances plant growth [234]. The time required to enter the thermophilic phase is also reduced after biochar addition and the temperature of composting is increased, which improves the humification efficiency [235]. Moreover, biochar reduces the leaching of organic $\mathrm{C}, \mathrm{P}$ and $\mathrm{N}$ and promotes nutrient retention during the composting process. Zhang and Sun [236] observed an increase in nutrient content during green waste composting after the addition of $20 \%$ biochar combined to $35 \%$ mushroom compost $(\mathrm{w} / \mathrm{w})$. Similarly, Zhang et al. [229] recorded an increase in water-soluble nutrients $\left(\mathrm{PO}_{4}{ }^{3-}, \mathrm{K}^{+}\right.$and $\left.\mathrm{Ca}^{2+}\right)$ of the compost product after addition of $10-15 \%(w / w)$ of wheat straw derived-biochar. In the study performed by Jain et al. [235], the total nitrogen of the final compost increased by about $45 \%$ after the addition of biochar at a rate of $5 \%(w / w)$ as compared to the control. The ratio of $\mathrm{C} / \mathrm{N}(w / w)$ is one of the most important parameters controlling the composting efficiency of organic wastes, and its optimal value should be about 25:1 [237]. As biochars contain high content of $\mathrm{C}$, its addition could increase the $\mathrm{C} / \mathrm{N}$ ratio of raw feedstocks rich in N. Simultaneously, composting can increase the biochar O/C ratio following the acceleration of the biochar surface oxidation [238]. Addition of biochar combined with compost can bring the same benefits to soils as chemical fertilizers. Biochar recycles $\mathrm{P}$ and $\mathrm{C}$, and compost recycles $\mathrm{P}, \mathrm{N}, \mathrm{C}$, and K; a combined application of both materials promoted the recycling of macro and micronutrients necessary for plant growth [239]. The biochar application rate significantly influences the composting process. A high loading rate could induce desiccation in composting due to excessive aeration. Steiner et al. [240] reported that $10 \%$ to $15 \%$ loading rates could be considered as optimal, while other values of $20 \%$ [240] and $27 \%$ [241] have also been reported.

Since biochar starting feedstock and pyrolysis temperature are proved to influence biochar properties, these parameters can also influence the quality of the final composting product. Most of the biochars used in composting are produced from woody biomass (e.g., 
oak wood, beech wood, bamboo) and crop residues (e.g., wheat straw) by pyrolysis at temperatures ranging from 400 to $700{ }^{\circ} \mathrm{C}$ [229]. The joint application of biochar and compost and their interaction during composting can improve the effect of both materials [237]. Composting promotes the formation of carboxylic and phenolic groups on the biochar surface, which increases its reactivity [238], while biochar can affect the microbiological structure of the compost by affecting moisture, aeration, $\mathrm{pH}$, and nutrient contents of the compost $[242,243]$. The biochar porosity and its high surface area enhance qualitatively and quantitatively the composition of the microbial communities [244]. Liu et al. [245] found an increase in microbial growth by $15 \% \mathrm{CFU} / \mathrm{g}$ after addition of biochar to compost. Biochar addition was reportedly able to increase the abundance of $\mathrm{N}_{2} \mathrm{O}$-consuming bacteria, which reduces $\mathrm{N}_{2} \mathrm{O}$ emissions from biochar-amended compost during the maturation phase [246] and to reduce the abundance of pathogenic microorganisms during composting of organic wastes [247]. Furthermore, some studies reported the positive effect of biochar application on the enzyme's activity during composting. Jindo et al. [248] found that urease, phosphatase, and polyphenol oxidase activities increased by $30-40 \%$ in the biocharamended compost. Similarly, Du et al. [249] reported that biochar addition to sewage sludge compost increased the activity of enzymes such asaryl-sulfatase, b-glucosidase, phosphatase, and dehydrogenase.

Biochar addition during composting also reacts with heavy metals and contributes to their immobilization, which accordingly reduces the risks of applying compost to soils. In the study performed by Zhou et al. [250], passivation rates of $95 \%, 66 \%$ and $69 \%$ were reached for $\mathrm{Cu}, \mathrm{Pb}$ and $\mathrm{Cd}$, respectively, when biochar and commercial humic acid were added to pig manure compost. Similar results were found by Liu et al. [251], observing a reduction in the bioavailability of heavy metals, particularlyAs and $\mathrm{Pb}$, in compost based on sewage sludge. Wang et al. [252] reported that the addition of biochar mixed with zeolite induces an increase in the binding ability and affinity of humic acid and $\mathrm{Cu}$ and $\mathrm{Zn}$ forming humic acid-complexed $\mathrm{Cu}$ and humic acid-complexed $\mathrm{Zn}$, which enhanced the immobilization of heavy metals. The addition of biochar during the composting process has been also proved to control the GHG emissions from compost [232,253,254]. The release of $\mathrm{NH}_{3}$ and $\mathrm{NH}_{4}{ }^{+}$during the composting process as a result of organic matter mineralization under increased temperature, $\mathrm{pH}$ and aeration, could be reduced after the addition of biochar due to its porous structure and its high adsorption capacity [253]. According to Wang et al. [254], the addition of 10\% tobacco stalk biochar combined with $10 \%$ zeolite and $2 \%$ wood vinegar $(w / w)$ to pig manure compost allows for a reduction in $\mathrm{NH}_{3}$ loss by about $64.45 \%$, and a decrease in $\mathrm{CO}_{2}, \mathrm{CH}_{4}$ and $\mathrm{N}_{2} \mathrm{O}$ emissions by $33.90 \%, 50.39 \%$ and $79.51 \%$, respectively. Opposite results have been found, however, such as by Czekala et al. [255], who observed an increase in $\mathrm{CO}_{2}$ emissions due to the increase in pile temperature after biochar application.

\section{Limitations}

Although the majority of research studies reported beneficial aspects of biochar use as a soil amendment, others reported insignificant or sometimes negative results, giving rise to some apprehension regarding its large-scale and long-term application. The availability of biochar could be a limitation to its application; biochar may not be sufficiently available to reach significant positive results. Furthermore, the positive impact of biochar has been reported to be soil-specific; its application may not be beneficial for all types of soil $[256,257]$. Other problems related to biochar application were also reported. SafaeiKhorram et al. [258] recorded an increase in weed growth by $200 \%$ during lentil culture after biochar application at a rate of $15 \mathrm{t} / \mathrm{ha}$. The effect of biochar on crop productivity varies depending on the plant species and the target part of the plant. Vaccari et al. [259] observed no fruit yield of tomato plants after the addition of biochar at $14 \mathrm{t} / \mathrm{ha}$, while an increase in vegetative growth was recorded. A delay in flowering for plants was also observed because of biochar addition to the soil [260]. Biochar may also be selective, and in some cases its addition does not import any immobilization effect towards some contaminants in soil [261]. The higher ash content 
of biochars produced at high temperatures may also induce detrimental effects on plants growth [262]. Another limitation of biochar amendment is its ability to adsorb essential nutrients for plant growth and then act as a competitor, which can be counterproductive to crop productivity $[263,264]$. For instance, the addition of biochar and phosphorous fertilizer in saline sodic soil promotes the precipitation/sorption reactions of phosphate and thus reduce the availability of phosphorous for plants [149]. Addition of biochar in soils may also cause a disturbance in organic matter decomposition, which may decrease the abundance of fungi species such as Ascomycota and Basidiomycota [265]. Other inconsistent effects may also occur depending on the biochar starting feedstock. In the study performed by Gonzaga et al. [266], soils treated by coconut husk biochar at $30 \mathrm{t} / \mathrm{ha}$ allowed for an improvement of the Zea mays biomass by about $90 \%$, while no significant effect was observed with orange bagasse biochar applied at the same rate. The application of biochar derived from some nutrient-poor biomasses may also limit their efficiency in improving crop productivity, which may require its combined application with compost or some chemical or organic fertilizers. Additionally, some feedstock used for biochar preparation may contain contaminant substances, which in turn affect plant growth [267]. Unless a good number of studies prove that these limitations can be overcome, the future of biochar for agricultural applications may be uncertain [154]. Crucial examination of all factors should be performed to prevent any potential detrimental effects of biochar that can limit its large-scale application. More research is after all needed to explore all mechanisms and to assess the long-term risk of biochar agronomic applications.

\section{Conclusions}

This review deals with the beneficial role of biochar in different agricultural applications. Biochar'sphysico-chemical properties, which depend on many variables such as biomass source, pyrolysis conditions, biochar ageing, determine its various agronomic functions. Biochar can act as a soil amendment, as a co-substrate in composting and as a feed additive to improve livestock productivity. The effect of biochar amendments in mitigating greenhouse gas emissions has also been proven. However, and based on literature findings, benefits of biochar application in agriculture are often limited to specific conditions. For instance, biochar can significantly improve soil properties and crops yield for certain soils and certain plants, while showing no significant effect or sometimes negative effect on other soils. This can be due to the large variety in biochar properties but also to the variety in soil types, crops specificity, climate conditions and the difficulty to predict the real interaction between biochar and soil nutrients and contaminants. This makes it difficult to decide on the appropriate biochar for the appropriate agricultural application. Hence, the real challenge is not the feasibility and efficacy of biochar application, but rather the selection of the appropriate biomass and pyrolysis conditions to produce specific biochars for specific purposes. Moreover, most of the studies presented so far were performed under laboratory conditions, which make the underlined conclusions unsuitable to cover all biochar effects and to define all limitations that could be related to its application. More experiments are therefore needed to evaluate the longevity of biochar's impact in agriculture under realistic conditions.

Author Contributions: Conceptualization, G.E. and M.L.; writing-original draft preparation, G.E. and M.L.; writing-review and editing, G.E. and M.L. Both authors have read and agreed to the published version of the manuscript.

Funding: This research received no external funding.

Conflicts of Interest: The authors declare no conflict of interest.

\section{References}

1. Adejumo, I.; Adebiyi, O. Agricultural Solid Wastes: Causes, Effects, and Effective Management. In Strategies of Sustainable Solid Waste Management; Hosam, S., Ed.; IntechOpen: London, UK, 2021.

2. Food and Agriculture Organization of the United Nations (FAO) Organization for Economic Co-Operation and Development (oecd). Background Notes on Sustainable, Productive and Resilient Agro-Food Systems: Value Chains, Human Capital, and the 
2030 Agenda. A Report to the G20 Agriculture Deputies. Available online: https:/ /www.oecdilibrary.org/docserver/dca82200 -en.df?expires=1563959111id=idaccname=guestchecksum=5bd0a7a51327db165936b4ae57a0e5ce (accessed on 13 August 2020).

3. Food and Agriculture Organization of the United Nations (FAO). Strategic Work of FAO for Sustainable Food and Agriculture. Available online: http:/ / www.FAO.org/3/a-i6488e.pdf (accessed on 13 August 2020).

4. Smith, P.; Martino, D.; Cai, Z.; Gwary, D.; Janzen, H.; Kumar, P.; McCarl, B.; Ogle, S.; O’Mara, F.; Rice, C.; et al. Greenhouse gas mitigation in agriculture. Philos. Trans. R. Soc. Lond. B Biol. Sci. 2008, 363, 789-813. [CrossRef]

5. Food and Agriculture Organization of the United Nations (FAO). The State of Food and Agriculture. Climate Change, Agriculture and Food Security. Available online: http:/ / www.fao.org/3/a-i6030e.pdf (accessed on 13 August 2020).

6. Casarejos, F.; Bastos, C.R.; Rufin, C.; Frota, M.N. Rethinking packaging production and consumption vis a vis circular economy: A case study of compostable cassava starch-based material. J. Clean. Prod. 2018, 201, 1019-1028. [CrossRef]

7. Maaß, O.; Grundmann, P. Governing transactions and interdependences between linked value chains in a circular economy: The case of wastewater reuse in Braunschweig (Germany). Sustainability 2018, 10, 1125. [CrossRef]

8. Ellen MacArthur Foundation. Towards a Circular Economy-Economic and Business Rationale for an Accelerated Transition; Ellen MacArthur Foundation: Cowes, UK, 2013.

9. Donia, E.; Mineo, A.; Sgroi, F. A methodological approach for assessing business investments in renewable resources from a circular economy perspective. Land Use Pol. 2018, 76, 823-827. [CrossRef]

10. Kilkis, S.; Kilkis, B. Integrated circular economy and education model to address aspects of an energy water food nexus in a dairy facility and local contexts. J. Clean. Prod. 2017, 167, 1084-1098. [CrossRef]

11. Caruso, M.; Braghieri, A.; Capece, A.; Napolitano, F.; Romano, P.; Galgano, F.; Altieri, G.; Genovese, F. Recent updates on the use of agro-food waste for biogas production. Appl. Sci. 2019, 9, 1217. [CrossRef]

12. Mosquera-Losada, M.; Amador-García, A.; Rigueiro-Rodríguez, A.; Ferreiro-Domínguez, N. Circular economy: Using lime stabilized bio-waste based fertilisers to improve soil fertility in acidic grasslands. Catena 2019, 179, 119-128. [CrossRef]

13. Bekchanov, M.; Mirzabaev, A. Circular economy of composting in Sri Lanka: Opportunities and challenges for reducing waste related pollution and improving soil health. J. Clean. Prod. 2018, 202, 1107-1119. [CrossRef]

14. Amoah-Antwi, C.; Kwiatkowska-Malina, J.; Thornton, S.; Fenton, O.; Malina, G.; Szara, E. Restoration of soil quality using biochar and brown coal waste: A review. Sci. Total Environ. 2020, 722, 137852. [CrossRef]

15. Tan, R. Data challenges in optimizing biochar-based carbon sequestration. Renew. Sustain. Energy Rev. 2019, 104, 174-177. [CrossRef]

16. Akhtar, S.; Andersen, M.; Liu, F. Residual effects of biochar on improving growth, physiology and yield of wheat under salt stress. Agric. Water Manag. 2015, 158, 61-68. [CrossRef]

17. Calvo, P.; Nelson, L.; Kloepper, J. Agricultural uses of plant biostimulants. Plant Soil 2014, 383, 3-41. [CrossRef]

18. Kaetzl, K.; Lübken, M.; Nettmann, E.; Krimmler, S.; Wichern, M. Slow sand filtration of raw wastewater using biochar as an alternative filtration media. Sci. Rep. 2020, 10, 1229. [CrossRef]

19. Kaetzl, K.; Lübken, M.; Uzuna, G.; Gehring, T.; Nettmanna, E.; Stenchly, K.; Wichern, M. On-farm wastewater treatment using biochar from local agroresidues reduces pathogens from irrigation water for safer food production in developing countries. Sci. Total Environ. 2019, 682, 601-610. [CrossRef]

20. Kaetzl, K.; Lübken, M.; Gehring, T.; Wichern, M. Efficient low-cost anaerobic treatment of wastewater using biochar and woodchip filters. Water 2018, 10, 818. [CrossRef]

21. Dugdug, A.; Chang, S.; Ok, Y.; Rajapaksha, A.; Anyia, A. Phosphorus sorption capacity of biochars varies with biochar type and salinity level. Environ. Sci. Pollut. Res. 2018, 25, 25799-25812. [CrossRef]

22. Karunanayake, A.; Todd, O.; Crowley, M.; Ricchetti, L.; Pittman, C.; Anderson, R.; Mohan, D.; Mlsna, T. Lead and cadmium remediation using magnetized and nonmagnetized biochar from Douglas fir. Chem. Eng. J. 2018, 331, 480-491. [CrossRef]

23. Rizwan, M.; Ali, S.; Abbas, T.; Adrees, M.; Ziaur Rehman, M.; Ibrahim, M.; Abbas, F.; Qayyum, M.; Nawaz, R. Residual effects of biochar on growth, photosynthesis and cadmium uptake in rice (Oryza sativa L.) under Cd stress with different water conditions. J. Environ. Manag. 2018, 206, 676-683. [CrossRef] [PubMed]

24. Barnes, R.; Gallagher, M.; Masiello, C.; Liu, Z.; Dugan, B. Biochar-induced changes in soil hydraulic conductivity and dissolved nutrient fluxes constrained by laboratory experiments. PLOS ONE 2014, 9, e108340.

25. Zhang, M.; Ok, Y. Biochar soil amendment for sustainable agriculture with carbon and contaminant sequestration. Carbon Manag. 2014, 5, 255-257. [CrossRef]

26. Blanco-Canqui, H. Biochar and soil physical properties. Soil Sci. Soc. Am. J. 2017, 81, 687-692. [CrossRef]

27. El-Naggar, A.; Awad, Y.; Tang, X.; Liu, C.; Niazi, N.; Jien, S.; Tsang, D.; Song, H.; Yong, S.; Sang, S. Biochar influences soil carbon pools and facilitates interactions with soil: A field investigation. Land Degrad. Dev. 2018, 29, 2162-2171. [CrossRef]

28. Sheng, Y.; Zhu, L. Biochar alters microbial community and carbon sequestration potential across different soil pH. Sci. Total Environ. 2018, 622, 1391-1399. [CrossRef]

29. Ahmad, M.; Rajapaksha, A.; Lim, J.; Zhang, M.; Bolan, N.; Mohan, D.; Vithanage, M.; Lee, S.; Ok, Y. Biochar as a sorbent for contaminant management in soil and water: A review. Chemosphere 2014, 99, 19-33. [CrossRef] [PubMed]

30. Bashir, S.; Zhu, J.; Fu, Q.; Hu, H. Cadmium mobility, uptake and anti-oxidative response of water spinach (ipomoea aquatic) under rice straw biochar, zeolite and rock phosphate as amendments. Chemosphere 2018, 194, 579-587. [CrossRef] 
31. Sandhu, S.; Dan, U.; Kumar, S.; Chintala, R.; Papiernik, S.; Malo, D.; Schumacher, T. Analyzing the impacts of three types of biochar on soil carbon fractions and physiochemical properties in a corn soybean rotation. Chemosphere 2017, 184, 473-481. [CrossRef] [PubMed]

32. Sun, X.; Han, X.; Ping, F.; Zhang, L.; Zhang, K.; Chen, M.; Wu, W. Effect of rice-straw biochar on nitrous oxide emissions from paddy soils under elevated $\mathrm{CO}_{2}$ and temperature. Sci. Total Environ. 2018, 28, 629-1009. [CrossRef] [PubMed]

33. Das, S.; Ghosh, G.; Avasthe, R. Biochar amendments on physico-chemical and biological properties of soils. Agrica 2017, 6, 79-87. [CrossRef]

34. Das, S.K.; Ghosh, G.K.; Avasthe, R. Applications of biomass derived biochar in modern science and technology. Environ. Technol. Innov. 2021, 21, 101306. [CrossRef]

35. Beesley, L.; Moreno-Jimenez, E.; Gomez-Eyles, J.; Harris, E.; Robinson, B.; Sizmur, T. A review of biochars' potential role in the remediation, revegetation and restoration of contaminated soils. Environ. Pollut. 2011, 159, 3269-3282. [CrossRef]

36. Uchimiya, M.; Wartelle, L.; Klasson, K.; Fortier, C.; Lima, I. Influence of pyrolysis temperature on biochar property and function as a heavy metal sorbent in soil. J. Agric. Food Chem. 2011, 59, 2501-2510. [CrossRef] [PubMed]

37. Barrow, C. Biochar: Potential for countering land degradation and for improving agriculture. Appl. Geogr. 2012, 34, 21-28. [CrossRef]

38. Wang, S.; Gao, B.; Zimmerman, A.; Li, Y.; Ma, L.; Harris, W.; Migliaccio, K. Physicochemical and sorptive properties of biochars derived from woody and herbaceous biomass. Chemosphere 2015, 134, 257-262. [CrossRef] [PubMed]

39. Weber, K.; Quicker, P. Properties of biochar. Fuel 2018, 217, 240-261. [CrossRef]

40. Yu, H.; Zou, W.; Chen, J.; Chen, H.; Yu, Z.; Huang, J.; Tang, H.; Wei, X.; Ga, B. Biochar amendment improves crop production in problem soils: A review. J. Environ. Manag. 2019, 232, 8-21. [CrossRef] [PubMed]

41. Brewer, C.; Chuang, V.; Masiello, C.; Gonnermann, H.; Gao, X.; Dugan, B.; Driver, L.; Panzacchi, P.; Zygourakis, K.; Davies, C. New approaches to measuring biochar density and porosity. Biomass Bioenergy 2014, 66, 176-185. [CrossRef]

42. Somerville, M.; Jahanshahi, S. The effect of temperature and compression during pyrolysis on the density of charcoal made from australian eucalypt wood. Renew. Energy 2015, 80, 471-478. [CrossRef]

43. Xiao, X.; Chen, B.; Chen, Z.; Zhu, L.; Schnoor, J. Insight into multiple and multilevel structures of biochars and their potential environmental applications: A critical review. Environ. Sci. Technol. 2018, 52, 5027-5047. [CrossRef]

44. Shaaban, M.; Zwieten, L.V.; Bashir, S.; Younas, A.; N’uñez-Delgado, A.; Chhajro, M.A.; Kubar, K.A.; Ali, U.; Rana, M.S.; Mehmood, M.A.; et al. A concise review of biochar application to agricultural soils to improve soil conditions and fight pollution. J. Environ. Manag. 2018, 228, 429-440. [CrossRef]

45. Zhang, H.; Voroney, R.; Price, G. Effects of temperature and processing conditions on biochar chemical properties and their influence on soil C and N transformations. Soil Biol. Biochem. 2015, 83, 19-28. [CrossRef]

46. Yu, H.; Zhang, Z.; Li, Z.; Chen, D. Characteristic of tar formation during cellulose, hemicellulose and lignin gasification. Fuel 2014, 118, 225-256. [CrossRef]

47. Wu, H.; Che, X.; Ding, Z.; Hu, X.; Creamer, A.; Chen, H.; Gao, B. Release of soluble elements from biochars derived from various biomass feedstocks. Environ. Sci. Pollut. Control Ser. 2016, 23, 1905-1915. [CrossRef] [PubMed]

48. Enaime, G.; Baçaoui, A.; Yaacoubi, A.; Wichern, M.; Lübken, M. Hydrothermal carbonization of the filter bed remained after filtration of olive mill wastewater on olive stones for biofuel application. Biomass Conv. Bioref. 2020. [CrossRef]

49. Abdul, G.; Zhu, X.; Chen, B. Structural characteristics of biochar-graphene nanosheet composites and their adsorption performance for phthalic acid esters. Chem. Eng. J. 2017, 319, 9-20. [CrossRef]

50. Li, H.; Mahyoub, S.; Liao, W.; Xia, S.; Zhao, H.; Guo, M.; Ma, P. Effect of pyrolysis temperature on characteristics and aromatic contaminants adsorption behavior of magnetic biochar derived from pyrolysis oil distillation residue. Bioresour. Technol. 2016, 223, 20-26. [CrossRef]

51. Cayuela, M.; Jeffery, S.; van Zwieten, L. The molar H: Corg ratio of biochar is a key factor in mitigating $\mathrm{N}_{2} \mathrm{O}$ emissions from soil. Agric. Ecosyst. Environ. 2015, 202, 135-138. [CrossRef]

52. Liang, C.; Gascó, G.; Fu, S.; Méndez, A.; Paz-Ferreiro, J. Biochar from pruning residues as a soil amendment: Effects of pyrolysis temperature and particle size. Soil Tillage Res. 2016, 164, 3-10. [CrossRef]

53. Wang, J.; Pan, X.; Liu, Y.; Zhang, X.; Xiong, Z. Effects of biochar amendment in two soils on greenhouse gas emissions and crop production. Plant Soil 2012, 360, 287-298. [CrossRef]

54. Naeem, M.; Khalid, M.; Ahmad, Z.; Naveed, M. Low pyrolysis temperature biochar improves growth and nutrient availability of maize on typic calciargid. Commun. Soil Sci. Plant Anal. 2016, 47, 41-51. [CrossRef]

55. Singh, B.; Macdonald, L.; Kookana, R.; van Zwieten, L.; Butler, G.; Joseph, S.; Weatherley, A.; Kaudal, B.; Regan, A.; Cattle, J. Opportunities and constraints for biochar technology in Australian agriculture: Looking beyond carbon sequestration. Soil Res. 2014, 52, 739-750. [CrossRef]

56. Meier, S.; Curaqueo, G.; Khan, N.; Bolan, N.; Cea, M.; Eugenia, G.; Cornejo, P.; Yong, S.; Borie, F. Chicken manure-derived biochar reduced bioavailability of copper in a contaminated soil. J. Soils Sediments 2017, 17, 741-750. [CrossRef]

57. Zornoza, R.; Moreno-Barriga, F.; Acosta, J.; Muñoz, M.; Faz, A. Stability, nutrient availability and hydrophobicity of biochars derived from manure, crop residues, and municipal solid waste for their use as soil amendments. Chemosphere 2016, 144, 122-130. [CrossRef] [PubMed] 
58. Zhao, L.; Cao, X.; Mašek, O.; Zimmerman, A. Heterogeneity of biochar properties as a function of feedstock sources and production temperatures. J. Hazard. Mater. 2013, 256, 1-9. [CrossRef] [PubMed]

59. Cheng, H.; Jones, D.L.; Hill, P.; Bastami, M.S.; Tu, C. Influence of biochar produced from different pyrolysis temperature on nutrient retention and leaching. Arch. Agron. Soil Sci. 2017, 64, 850-859. [CrossRef]

60. Gai, X.; Wang, H.; Liu, J.; Zhai, L.; Liu, S.; Ren, T.; Liu, H. Effects of feedstock and pyrolysis temperature on biochar adsorption of ammonium and nitrate. PLoS ONE 2014, 9, e113888. [CrossRef]

61. Rafiq, M.K.; Bachmann, R.T.; Rafiq, M.T.; Shang, Z.; Joseph, S.; Long, R. Influence of pyrolysis temperature on physico-chemical properties of corn stover (Zea mays L.) biochar and feasibility for carbon capture and energy balance. PLoS ONE 2016, 11, e0156894. [CrossRef]

62. Nwajiaku, I.M.; Olanrewaju, J.S.; Sato, K.; Tokunari, T.; Kitano, S.; Masunaga, T. Change in nutrient composition of biochar from rice husk and sugarcane bagasse at varying pyrolytic temperatures. Int. J. Recycl. Org. Waste Agric. 2018, 7, 269-276. [CrossRef]

63. Domingues, R.; Trugilho, P.; Silva, C.; de Melo, I.; Melo, L.; Magriotis, Z.; Sánchez-Monedero, M. Properties of biochar derived from wood and high-nutrient biomasses with the aim of agronomic and environmental benefits. PLoS ONE 2017, 12, e0176884. [CrossRef]

64. Zhao, S.-X.; Ta, N.; Wang, X.-D. Effect of temperature on the structural and physicochemical properties of biochar with apple tree branches as feedstock material. Energies 2017, 10, 1293. [CrossRef]

65. Liu, J.; Ding, Y.; Ji, Y.; Gao, G.; Wang, Y. Effect of maize straw, biochar on bacterial communities in agricultural soil. Bull. Environ. Contam. Toxicol. 2020, 104, 333-338. [CrossRef]

66. Meng, J.; Wang, L.; Liu, X.; Wu, J.; Brookes, P.C.; Xu, J. Physicochemical properties of biochar produced from aerobically composted swine manure and its potential use as an environmental amendment. Bioresour. Technol. 2013, 142, 641-646. [CrossRef]

67. Kim, W.-K.; Shim, T.; Kim, Y.-S.; Hyun, S.; Ryu, C.; Park, Y.-K.; Jung, J. Characterization of cadmium removal from aqueous solution by biochar produced from a giant miscanthus at different pyrolytic temperatures. Bioresour. Technol. 2013, 138, 266-270. [CrossRef]

68. Beesley, L.; Marmiroli, M.; Pagano, L.; Pigoni, V.; Fellet, G.; Fresno, T.; Vamerali, T.; Bandiera, M.; Marmiroli, N. Biochar addition to an arsenic contaminated soil increases arsenic concentrations in the pore water but reduces uptake to tomato plants (Solanum lycopersicum L.). Sci. Total Environ. 2013, 454-455, 598-603. [CrossRef] [PubMed]

69. Sun, F.; Lu, S. Biochars improve aggregate stability, water retention, and pore space properties of clayey soil. J. Plant Nutr. Soil Sci. 2014, 177, 26-33. [CrossRef]

70. Amin, A.; Eissa, M. Biochar effects on nitrogen and phosphorus use efficiencies of zucchini plants grown in a calcareous sandy. $J$ Soil Sci. Plant Nutr. 2017, 17, 912-921. [CrossRef]

71. Wang, H.; Zheng, H.; Jiang, Z.; Dai, Y.; Liu, G.; Chen, L.; Luo, X.; Liu, M.; Wang, Z. Efficacies of biochar and biochar-based amendment on vegetable yield and nitrogen utilization in four consecutive planting seasons. Sci. Total Environ. 2017, 593-594, 124-133. [CrossRef]

72. Cao, H.; Ning, L.; Xun, M.; Feng, F.; Li, P.; Yue, S.; Song, J.; Zhang, W.; Yang, H. Biochar can increase nitrogen use efficiency of Malus hupehensis by modulating nitrate reduction of soil and root. Appl. Soil Ecol. 2019, 135, 25-32. [CrossRef]

73. Eyles, A.; Bound, S.; Oliver, G.; Corkrey, R.; Hardie, M.; Green, S.; Close, D. Impact of biochar amendment on the growth, physiology and fruit of a young commercial apple orchard. Trees 2015, 29, 1817-1826. [CrossRef]

74. Ge, X.; Cao, Y.; Zhou, B.; Wang, X.; Yang, Z.; Li, M. Biochar addition increases subsurface soil microbial biomass but has limited effects on soil $\mathrm{CO}_{2}$ emissions in subtropical moso bamboo plantations. Appl. Soil Ecol. 2019, 142, 155-165. [CrossRef]

75. Alburquerque, J.; Calero, J.; Barrón, V.; Torrent, J.; del Campillo, M.; Gallardo, A.; Villar, R. Effects of biochars produced from different feedstocks on soil properties and sunflower growth. J. Plant Nutr. Soil Sci. 2014, 177, 16-25. [CrossRef]

76. Fiaz, K.; Younis, U.; Danish, S.; Shah, M.; Niaz, S. Drought impact on Pb/Cd toxicity remediated by biochar in Brassica campestris. J. Plant Nutr. Soil Sci. 2014, 14, 845-854. [CrossRef]

77. Akhtar, S.; Andersen, M.; Liu, F. Biochar mitigates salinity stress in potato. J. Agron. Crop Sci. 2015, 201, 368-378. [CrossRef]

78. Hafeez, Y.; Iqbal, S.; Jabeen, K.; Shahzad, S.; Jahan, S.; Rasul, F. Effect of biochar application on seed germination and seedling growth of glycine max (L.) merr. under drought stress. Pak. J. Bot. 2017, 49, 7-13.

79. Pressler, Y.; Foster, E.; Moore, J.; Cotrufo, M. Coupled biochar amendment and limited irrigation strategies do not affect a degraded soil food web in a maize agroecosystem, compared to the native grassland. GCB Bioenergy 2017, 9, 1344-1355. [CrossRef]

80. Lashari, M.; Ye, Y.; Ji, H.; Li, L.; Kibue, G.; Lu, H.; Zheng, J.; Pan, G. Biochar-manure compost in conjunction with pyroligneous solution alleviated salt stress and improved leaf bioactivity of maize in a saline soil from central china: A 2-year field experiment. J. Sci. Food Agric. 2015, 95, 1321-1327. [CrossRef]

81. Hammer, E.; Forstreuter, M.; Rillig, M.; Kohler, J. Biochar increases arbuscular mycorrhizal plant growth enhancement and ameliorates salinity stress. Appl. Soil Ecol. 2015, 96, 114-121. [CrossRef]

82. Dong, D.; Feng, Q.; McGrouther, K.; Yang, M.; Wang, H.; Wu, W. Effects of biochar amendment on rice growth and nitrogen retention in a waterlogged paddy field. J. Soils Sediments 2015, 15, 153-162. [CrossRef]

83. Barati, M.; Bakhtiari, F.; Mowla, D.; Safarzadeh, S. Comparison of the effects of poultry manure and its biochar on barley growth in petroleum-contaminated soils. Int. J. Phytoremediat. 2018, 20, 98-103. [CrossRef] 
84. Brennan, A.; Moreno Jimenez, E.; Alburquerque, J.; Knapp, C.; Switzer, C. Effects of biochar and activated carbon amendment on maize growth and the uptake and measured availability of polycyclic aromatic hydrocarbons (PAHs) and potentially toxic elements (PTEs). Environ. Pollut. 2014, 193, 79-87. [CrossRef]

85. Xu, R.; Zhao, A.; Yuan, J.; Jiang, J. pH buffering capacity of acid soils from tropical and subtropical regions of china as influenced by incorporation of crop straw biochars. J. Soil Sediment 2012, 12, 494-502. [CrossRef]

86. Major, J.; Rondon, M.; Molina, D.; Riha, S.; Lehmann, J. Maize yield and nutrition during 4 years after biochar application to a colombian savanna oxisol. Plant Soil 2010, 333, 117-128. [CrossRef]

87. Atkinson, C.; Fitzgerald, J.; Hipps, N. Potential mechanisms for achieving agricultural benefits from biochar application to temperate soils: A review. Plant Soil 2010, 337, 1-18. [CrossRef]

88. Agegnehu, G.; Srivastava, A.; Bird, M. The role of biochar and biochar-compost in improving soil quality and crop performance: A review. Appl. Soil Ecol. 2017, 119, 156-170. [CrossRef]

89. Naeem, M.; Khalid, M.; Aon, M.; Abbas, G.; Amjad, M.; Murtaza, B.; Khan, W.-U.-D.; Ahmad, N. Combined application of biochar with compost and fertilizer improves soil properties and grain yield of maize. J. Plant Nutr. 2018, 41, 112-122. [CrossRef]

90. Liang, B.; Lehmann, J.; Solomon, D.; Kinyangi, J.; Grossman, J.; O’Neill, B.; Skjemstad, J.O.; Thies, J.; Luizão, F.J.; Petersen, J.; et al. Black carbon increases cation exchange capacity in soils. Soil Sci. Soc. Am. J. 2006, 70, 1719-1730. [CrossRef]

91. Rehman, H.; Razzaq, R. Benefits of biochar on the agriculture and environment-A review. J. Environ. Anal. Chem. 2017, 4, 1-3. [CrossRef]

92. Jien, S.-H.; Wang, C.-S. Effects of biochar on soil properties and erosion potential in a highly weathered soil. Catena 2013, 110, 225-233. [CrossRef]

93. Huang, M.; Yang, L.; Qin, H.; Jiang, L.; Zou, Y. Quantifying the effect of biochar amendment on soil quality and crop productivity in chinese rice paddies. Field Crop. Res. 2013, 154, 172-177. [CrossRef]

94. Agegnehu, G.; Bass, A.; Nelson, P.; Muirhead, B.; Wright, G.; Bird, M. Biochar and biochar-compost as soil amendments: Effects on peanut yield, soil properties and greenhouse gas emissions in tropical north queensland, Australia. Agric. Ecosyst. Environ. 2015, 213, 72-85. [CrossRef]

95. Hussain, M.; Farooq, M.; Nawaz, A.; Al-Sadi, A.; Solaiman, Z.; Alghamdi, S.; Ammara, U.; Ok, Y.; Siddique, K. Biochar for crop production: Potential benefits and risks. J. Soil Sediment 2017, 17, 685-716. [CrossRef]

96. Mukherjee, A.; Lal, R.; Zimmerman, A. Effects of biochar and other amendments on the physical properties and greenhouse gas emissions of an artificially degraded soil. Sci. Total Environ. 2014, 487, 26-36. [CrossRef] [PubMed]

97. Anyika, C.; Majid, Z.; Rashid, M.; Isa, A.; Ismail, N.; Zakaria, M.; Yahya, A. Toxic and nontoxic elemental enrichment in biochar at different production temperatures. J. Clean. Prod. 2016, 131, 810-821. [CrossRef]

98. Bass, A.; Bird, M.; Kay, G.; Muirhead, B. Soil properties, greenhouse gas emissions and crop yield under compost, biochar and co-composted biochar in two tropical agronomic systems. Sci. Total Environ. 2016, 550, 459-470. [CrossRef]

99. Liu, C.; Wang, H.; Tang, X.; Guan, Z.; Reid, B.J.; Rajapaksha, A.U.; Ok, Y.S.; Sun, H. Biochar increased water holding capacity but accelerated organic carbon leaching from a sloping farmland soil in china. Environ. Sci. Pollut. Res. Int. 2016, 23, 995-1006. [CrossRef] [PubMed]

100. Igalavithana, A.D.; Ok, Y.S.; Niazi, N.K.; Rizwan, M.; Al-Wabel, M.I.; Usman, A.R.A.; Moon, D.H.; Lee, S. Effect of corn residue biochar on the hydraulic properties of sandy loam soil. Sustainability 2017, 9, 266. [CrossRef]

101. Rasa, K.; Heikkinen, J.; Hannula, M.; Arstila, K.; Kulju, S.; Hyväluoma, J. How and why does willow biochar increase a clay soil water retention capacity? Biomass Bioenergy 2018, 119, 346-353. [CrossRef]

102. Ogura, T.; Date, Y.; Masukujane, M.; Coetzee, T.; Akashi, K.; Kikuchi, J. Improvement of physical, chemical, and biological properties of aridisol from botswana by the incorporation of torrefied biomass. Sci. Rep. 2016, 6, 28011. [CrossRef] [PubMed]

103. Are, K.S.; Adelana, A.O.; Fademi, I.O.; Aina, O.A. Improving physical properties of degraded soil: Potential of poultry manure and biochar. Agric. Nat. Resour. 2017, 51, 454-462. [CrossRef]

104. Paetsch, L.; Mueller, C.W.; Kögel-Knabner, I.; von Lützow, M.; Girardin, C.; Rumpel, C. Effect of in-situaged and fresh biochar on soil hydraulic conditions and microbial C use under drought conditions. Sci. Rep. 2018, 8, 6852. [CrossRef] [PubMed]

105. Aller, D. Scaling Understanding of Biochar Aging Impacts on Soil Water and Crop Yields. Ph.D. Thesis, Iowa State University, Ames, IA, USA, 2017; p. 208.

106. Liu, Z.; Dugan, B.; Masiello, C.; Gonnermann, H. Biochar particle size, shape, and porosity act together to influence soil water properties. PLoS ONE 2017, 12, e0179079. [CrossRef]

107. Omondi, M.; Xia, X.; Nahayo, A.; Liu, X.; Korai, P.; Pan, G. Quantification of biochar effects on soil hydrological properties using meta-analysis of literature data. Geoderma 2016, 274, 28-34. [CrossRef]

108. Jeffery, S.; Meinders, M.; Stoof, C.; Bezemer, T.; van de Voorde, T.; Mommer, L.; van Groenigen, J. Biochar application does not improve the soil hydrological function of a sandy soil. Geoderma 2015, 251, 47-54. [CrossRef]

109. Herath, H.; Camps-Arbestain, M.; Hedley, M. Effect of biochar on soil physical properties in two contrasting soils: An Alfisol and an Andisol. Geoderma 2013, 209, 188-197. [CrossRef]

110. Manolikaki, I.; Diamadopoulos, E. Ryegrass yield and nutrient status after biochar application in two mediterranean soils. Arch. Agron. Soil Sci. 2016, 63, 1093-1107. [CrossRef]

111. Steiner, C.; Bayode, A.; Ralebitso-Senior, T.K. Feedstock and Production Parameters. In Biochar Application: Essential Soil Microbial Ecology; Komang Ralebitso-Senior, T., Orr, C.H., Eds.; Elsevier: New York, NY, USA, 2016; pp. 41-54. 
112. Ding, Y.; Liu, Y.; Liu, S.; Li, Z.; Tan, X.; Huang, X.; Zeng, G.; Zhou, L.; Zheng, B. Biochar to improve soil fertility. A review. Agron. Sustain. Dev. 2016, 36, 1856. [CrossRef]

113. Hagemann, N.; Kammann, C.I.; Schmidt, H.-P.; Kappler, A.; Behrens, S. Nitrate capture and slow release in biochar amended compost and soil. PLoS ONE 2017, 12, e0171214. [CrossRef]

114. Libutti, A.; Mucci, M.; Francavilla, M.; Monteleone, M. Effect of biochar amendment on nitrate retention in a silty clay loam soil. Ital. J. Agron. 2016, 11, 273-276. [CrossRef]

115. Haider, G.; Steffens, D.; Moser, G.; Müller, C.; Kammann, C. Biochar reduced nitrate leaching and improved soil moisture content without yield improvements in a four-year field study. Agric. Ecosyst. Environ. 2017, 237, 80-94. [CrossRef]

116. Chen, Y.; Xin, L.; Liu, J.; Yuan, M.; Liu, S.; Jiang, W.; Chen, J. Changes in bacterial community of soil induced by long-term straw returning. Sci. Agric. 2017, 74, 349-356. [CrossRef]

117. Demiraj, E.; Libutti, A.; Malltezi, J.; Rroço, E.; Brahushi, F.; Monteleone, M.; Sulçe, S. Effect of organic amendments on nitrate leaching mitigation in a sandy loam soil of shkodra district, Albania. Ital. J. Agron. 2018, 13, 93. [CrossRef]

118. Wang, Y.; Liu, Y.; Liu, R.; Zhang, A.; Yang, S.; Liu, H.; Zhou, Y.; Yang, Z. Biochar amendment reduces paddy soil nitrogen leaching but increases net global warming potential in ningxia irrigation, china. Sci. Rep. 2017, 7, 1592. [CrossRef]

119. Nguyen, T.T.N.; Xu, C.-Y.; Tahmasbian, I.; Che, R.; Xu, Z.; Zhou, X.; Wallace, H.M.; Bai, S.H. Effects of biochar on soil available inorganic nitrogen: A review and meta-analysis. Geoderma 2017, 288, 79-96. [CrossRef]

120. Liu, Q.; Zhang, Y.; Liu, B.; Amonette, J.E.; Lin, Z.; Liu, G.; Ambus, P.; Xie, Z. How does biochar influence soil N cycle? A meta-analysis. Plant Soil 2018, 426, 211-225. [CrossRef]

121. Borchard, N.; Schirrmann, M.; Cayuela, M.L.; Kammann, C.; Wrage-Mönnig, N.; Estavillo, J.M.; Fuertes-Mendizábal, T.; Sigua, G.; Spokas, K.; Ippolito, J.A.; et al. Biochar, soil and land-use interactions that reduce nitrate leaching and $\mathrm{N}_{2} \mathrm{O}$ emissions: A meta-analysis. Sci. Total Environ. 2019, 651, 2354-2364. [CrossRef] [PubMed]

122. Liang, Y.; Cao, X.; Zhao, L.; Xu, X.; Harris, W. Phosphorus release from dairy manure, the manure-derived biochar, and their amended soil: Effects of phosphorus nature and soil property. J. Environ. Qual. 2014, 43, 1504-1509. [CrossRef] [PubMed]

123. Hong, C.; Lu, S. Does biochar affect the availability and chemical fractionation of phosphate in soils? Environ. Sci. Pollut. Res. Int. 2018, 25, 8725-8734. [CrossRef] [PubMed]

124. Lehmann, J.; Rillig, M.C.; Thies, J.; Masiello, C.A.; Hockaday, W.C.; Crowley, D. Biochar effects on soil biota -a review. Soil Biol. Biochem. 2011, 43, 1812-1836. [CrossRef]

125. Siedt, M.; Schäffer, A.; Smith, K.; Nabel, M.; Roß-Nickoll, M.; van Dongen, J. Comparing straw, compost, and biochar regarding their suitability as agricultural soil amendments to affect soil structure, nutrient leaching, microbial communities, and the fate of pesticides. Sci. Total Environ. 2021, 751, 141607. [CrossRef]

126. Palansooriya, K.N.; Wong, J.T.F.; Hashimoto, Y.; Huang, L.; Rinklebe, J.; Chang, S.; Bolan, N.; Wang, H.; Ok, Y. Response of microbial communities to biochar-amended soils: A critical review. Biochar 2019, 1, 3-22. [CrossRef]

127. Jaiswal, A.; Elad, Y.; Paudel, I.; Graber, E.; Cytryn, E.; Frenkel, O. Linking the belowground microbial composition, diversity and activity to soilborne disease suppression and growth promotion of tomato amended with biochar. Sci. Rep. 2017, 7, 44382. [CrossRef] [PubMed]

128. Liao, H.; Li, Y.; Yao, H. Biochar amendment stimulates utilization of plant-derived carbon by soil bacteria in an intercropping system. Front. Microbiol. 2019, 10, 1361. [CrossRef] [PubMed]

129. Li, M.; Liu, M.; Li, Z.; Jiang, C.; Wu, M. Soil N transformation and microbial community structure as affected by adding biochar to a paddy soil of subtropical china. J. Integr. Agric. 2016, 15, 209-219. [CrossRef]

130. Han, G.; Lan, J.; Chen, Q.; Yu, C.; Bie, S. Response of soil microbial community to application of biochar in cotton soils with different continuous cropping years. Sci. Rep. 2017, 7, 10184. [CrossRef] [PubMed]

131. Orr, C.H.; Ralebitso-Senior, T.K.; Prior, S. Microbial ecology of the rhizosphere and its response to biochar augmentation. In Biochar Application: Essential Soil Microbial Ecology; Komang Ralebitso-Senior, T., Orr, C.H., Eds.; Elsevier: Amsterdam, The Netherlands, 2016; pp. 199-220.

132. Li, G.; Khan, S.; Ibrahim, M.; Sun, T.; Tang, J.; Cotner, J.; Xu, Y. Biochars induced modification of dissolved organic matter (DOM) in soil and its impact on mobility and bioaccumulation of arsenic and cadmium. J. Hazard. Mater. 2018, 348, 100-108. [CrossRef] [PubMed]

133. Rafique, M.; Sultan, T.; Ortas, I.; Chaudhary, H. Enhancement of maize plant growth with inoculation of phosphate-solubilizing bacteria and biochar amendment in soil. Soil. Sci. Plant Nutr. 2017, 63, 460-469. [CrossRef]

134. Elad, Y.; David, D.; Harel, Y.M.; Borenshtein, M.; Ben Kalifa, H.; Silber, A.; Graber, E. Induction of systemic resistance in plants by biochar, a soil-applied carbon sequestering agent. Phytopathology 2010, 100, 913-921. [CrossRef] [PubMed]

135. Harel, Y.; Elad, Y.; Rav-David, D.; Borenstein, M.; Shulchani, R.; Lew, B.; Graber, E. Biochar mediates systemic response of strawberry to foliar fungal pathogens. Plant Soil 2012, 357, 245-257. [CrossRef]

136. Huang, Z.; Lu, Q.; Wang, J.; Chen, X.; Mao, X.; He, Z. Inhibition of the bioavailability of heavy metals in sewage sludge biochar by adding two stabilizers. PLoS ONE 2017, 12, e0183617. [CrossRef]

137. Han, Y.; Douds, D., Jr.; Boateng, A. Effect of biochar soil-amendments on Allium porrum growth and arbuscular mycorrhizal fungus colonization. J. Plant Nutr. 2016, 39, 1654-1662. [CrossRef]

138. Akhter, A.; Hage-Ahmed, K.; Soja, G.; Steinkellner, S. Compost and biochar alter mycorrhization, tomato root exudation, and development of Fusarium oxysporum f. sp. Lycopersici. Front. Plant Sci. 2015, 6, 529. [CrossRef] 
139. Kavitha, B.; Reddy, P.; Kim, B.; Leed, S.S.; Pandeye, S.K.; Kim, K.-H. Benefits and limitations of biochar amendment in agricultural soils: A review. J. Environ. Manag. 2018, 227, 146-154. [CrossRef] [PubMed]

140. Luo, L.; Gu, J. Alteration of extracellular enzyme activity and microbial abundance by biochar addition: Implication for carbon sequestration in subtropical mangrove sediment. J. Environ. Manag. 2016, 182, 29-36. [CrossRef]

141. Bailey, V.; Fansler, S.; Smith, J.; Bolton, H., Jr. Reconciling apparent variability in effects of biochar amendment on soil enzyme activities by assay optimization. Soil Biol. Biochem. 2011, 43, 296-301. [CrossRef]

142. Uzoma, K.C.; Inoue, M.; Andry, H.; Fujimaki, H.; Zahoor, A.; Nishihara, E. Effect of cow manure biochar on maize productivity under sandy soil condition. Soil Use Manag. 2011, 27, 205-212. [CrossRef]

143. Houben, D.; Evrard, L.; Sonnet, P. Beneficial effects of biochar application to contaminated soils on the bioavailability of $\mathrm{Cd}$, Pb and $\mathrm{Zn}$ and the biomass production of rapeseed (Brassica napus L.). Biomass Bioenergy 2013, 57, 196-204. [CrossRef]

144. Hossain, M.K.; Strezov, V.; Yin Chan, K.; Nelson, P.F. Agronomic properties of wastewater sludge biochar and bioavailability of metals in production of cherry tomato (Lycopersicon esculentum). Chemosphere 2010, 78, 1167-1171. [CrossRef] [PubMed]

145. Gaskin, J.W.; Speir, R.A.; Harris, K.; Das, K.C.; Lee, R.D.; Morris, L.A.; Fisher, D.S. Effect of peanut hull and pine chip biochar on soil nutrients, corn nutrient status, and yield. Agron. J. 2010, 102, 623-633. [CrossRef]

146. Jones, D.; Edwards-Jones, G.; Murphy, D. Biochar mediated alterations in herbicide breakdown and leaching in soil. Soil Biol. Biochem. 2011, 43, 804-813. [CrossRef]

147. Chan, K.; Van Zwieten, L.; Meszaros, I.; Downie, A.; Joseph, S. Agronomic values of green waste biochar as a soil amendment. Aust. J. Soil Res. 2007, 45, 629-634. [CrossRef]

148. Borchard, N.; Siemens, J.; Ladd, B.; Möller, A.; Amelung, W. Application of biochars to sandy and silty soil failed to increase maize yield under common agricultural practice. Soil Tillage Res. 2014, 144, 184-194. [CrossRef]

149. Xu, G.; Zhang, Y.; Sun, J.; Shao, H. Negative interactive effects between biochar and phosphorus fertilization on phosphorus availability and plant yield in saline sodic soil. Sci. Total Environ. 2016, 568, 910-915. [CrossRef] [PubMed]

150. Hagemann, N.; Harter, J.; Kaldamukova, R.; Guzman-Bustamante, I.; Ruser, R.; Graeff, S.; Kappler, A.; Behrens, S. Does soil aging affect the $\mathrm{N}_{2} \mathrm{O}$ mitigation potential of biochar? A combined microcosm and field study. GCB Bioenergy 2017, 9, 953-964. [CrossRef]

151. Graber, E.; MellerHarel, Y.; Kolton, M.; Cytryn, E.; Silber, A.; Rav David, D.; Tsechansky, L.; Borenshtein, M.; Elad, Y. Biochar impact on development and productivity of pepper and tomato grown in fertigated soilless media. Plant Soil 2010, 337, 481-496. [CrossRef]

152. Enaime, G.; Baçaoui, A.; Yaacoubi, A.; Lübken, M. Biochar for wastewater treatment-conversion technologies and applications. Appl. Sci. 2020, 10, 3492. [CrossRef]

153. Tang, J.; Zhu, W.; Kookana, R.; Katayama, A. Characteristics of biochar and its application in remediation of contaminated soil. J. Biosci. Bioeng. 2013, 116, 653-659. [CrossRef] [PubMed]

154. Parmar, A.; Nema, P.; Agarwa, T. Biochar production from agro-food industry residues: A sustainable approach for soil and environmental management. Curr. Sci. 2014, 107, 1673-1682.

155. He, L.; Zhong, H.; Liu, G.; Dai, Z.; Brookes, P.; Xu, J. Remediation of heavy metal contaminated soils by biochar: Mechanisms, potential risks and applications in china. Environ. Pollut. 2019, 252, 846-855. [CrossRef]

156. Pidlisnyuk, V.; Newton, R.A.; Mamirova, A. Miscanthus biochar value chain-A review. J. Environ. Manag. 2021, $290,112611$. [CrossRef]

157. Beesley, L.; Moreno-Jiménez, E.; Gomez-Eyles, J.L. Effects of biochar and green waste compost amendments on mobility, bioavailability and toxicity of inorganic and organic contaminants in a multi element polluted soil. Environ. Pollut. 2010, 158, 2282-2287. [CrossRef]

158. Beesley, L.; Marmiroli, M. The immobilisation and retention of soluble arsenic, cadmium and zinc by biochar. Environ. Pollut. 2011, 159, 474-480. [CrossRef]

159. Kosseva, M.R. Management and processing of food wastes. In Advances in Food and Nutrition Research; Elservier: Amsterdam, The Netherlands, 2011; Volume 58, pp. 57-136.

160. Bashir, S.; Hussain, Q.; Akmal, M.; Riaz, M.; Hu, H.; Ijaz, S.; Iqbal, M.; Abro, S.; Mehmood, S.; Ahmad, M. Sugarcane bagassederived biochar reduces the cadmium and chromium bioavailability to mash bean and enhances the microbial activity in contaminated soil. J. Soils Sediments 2018, 18, 874-886. [CrossRef]

161. Pan, D.; Liu, C.; Yu, H.; Li, F. A paddy field study of arsenic and cadmium pollution control by using iron-modified biochar and silica sol together. Environ. Sci. Pollut. Res. 2019, 26, 24979-24987. [CrossRef] [PubMed]

162. Sui, F.; Zuo, J.; Chen, D.; Li, L.; Pan, G.; Crowley, D. Biochar effects on uptake of cadmium and lead by wheat in relation to annual precipitation: A 3-year field study. Environ. Sci. Pollut. Res. 2018, 25, 3368-3377. [CrossRef]

163. Karer, J.; Zehetner, F.; Dunst, G.; Fessl, J.; Wagner, M.; Puschenreiter, M.; Stapkevica, M.; Friesl-Hanl, W.; Soja, G. Immobilisation of metals in a contaminated soil with biochar-compost mixtures and inorganic additives: 2-year greenhouse and field experiments. Environ. Sci. Pollut. Res. 2018, 25, 2506-2516. [CrossRef]

164. Salam, A.; Bashir, S.; Khan, I.; Hu, H. Two years impacts of rapeseed residue and rice straw biochar on $\mathrm{Pb}$ and $\mathrm{Cu}$ immobilization and revegetation of naturally co-contaminated soil. Appl. Geochem. 2019, 105, 97-104. [CrossRef] 
165. Sui, F.; Wang, J.; Zuo, J.; Joseph, S.; Munroe, P.; Drosos, M.; Li, L.; Pan, G. Effect of amendment of biochar supplemented with Si on $\mathrm{Cd}$ mobility and rice uptake over three rice growing seasons in an acidic Cd-tainted paddy from central south china. Sci. Total Environ. 2020, 709, 136101. [CrossRef] [PubMed]

166. Wu, J.; Huang, D.; Liu, X.; Meng, J.; Tang, C.; Xu, J. Remediation of As(III) and Cd (II) co-contamination and its mechanism in aqueous systems by a novel calcium-based magnetic biochar. J. Hazard Mater. 2018, 348, 10-19. [CrossRef] [PubMed]

167. Nie, C.; Yang, X.; Niazi, N.; Xu, X.; Wen, Y.; Rinklebe, J.; Ok, Y.; Xu, S.; Wang, H. Impact of sugarcane bagasse-derived biochar on heavy metal availability and microbial activity: A field study. Chemosphere 2018, 200, 274-282. [CrossRef] [PubMed]

168. Chen, D.; Guo, H.; Li, R.; Li, L.; Pan, G.; Chang, A.; Joseph, S. Low uptake affinity cultivars with biochar to tackle Cd-tainted rice -A field study over four rice seasons in Hunan, China. Sci. Total Environ. 2016, 541, 1489-14982. [CrossRef]

169. Khan, S.; Reid, B.; Li, G.; Zhu, Y. Application of biochar to soil reduces cancer risk via rice consumption: A case study in Miaoqian village, Longyan, China. Environ. Int. 2014, 68, 154-161. [CrossRef]

170. Cui, L.; Li, L.; Mail, A.; Pan, G. Biochar amendment greatly reduces rice Cd uptake in a contaminated paddy soil: A two-year field experiment. Bioresources 2011, 6, 2605-2618.

171. Li, Z.; Qi, X.; Fan, X.; Du, Z.; Hu, C.; Zhao, Z.; Isa, Y.; Liu, Y. Amending the seedling bed of eggplant with biochar can further immobilize Cd in contaminated soils. Sci. Total Environ. 2016, 572, 626-633. [CrossRef]

172. Zhao, B.; Xu, R.; Ma, F.; Li, Y.; Wang, L. Effects of biochars derived from chicken manure and rape straw on speciation and phytoavailability of Cd to maize in artificially contaminated loess soil. J. Environ. Manag. 2016, 184, 569-574. [CrossRef] [PubMed]

173. Zhang, R.; Li, Z.; Liu, X.; Wang, B.; Zhou, G.; Huang, X.; Lin, C.; Wang, A.; Brooks, M. Immobilization and bioavailability of heavy metals in greenhouse soils amended with rice straw-derived biochar. Ecol. Eng. 2017, 98, 183-188. [CrossRef]

174. Khan, W.-D.; Ramzani, P.M.A.; Anjum, S.; Abbas, F.; Iqbal, M.; Yasar, A.; Ihsan, M.Z.; Anwar, M.N.; Baqar, M.; Tauqeer, H.M.; et al. Potential of miscanthus biochar to improve sandy soil health, in situ nickel immobilization in soil and nutritional quality of spinach. Chemosphere 2017, 185, 1144-1156. [CrossRef] [PubMed]

175. Bian, R.; Li, L.; Bao, D.; Zheng, J.; Zhang, X.; Liu, X.; Cheng, K.; Pan, G. Cd immobilization in a contaminated rice paddy by inorganic stabilizers of calcium hydroxide and silicon slag and by organic stabilizer of biochar. Environ. Sci. Pollut. Res. 2016, 23, 10028-10036. [CrossRef] [PubMed]

176. Clay, S.; Krack, K.; Bruggeman, S.; Papiernik, S.; Schumacher, T. Maize, switchgrass, and ponderosa pine biochar added to soil increased herbicide sorption and decreased herbicide efficacy. J. Environ. Sci. Health Part B 2016, 51, 497-507. [CrossRef] [PubMed]

177. Gonzaga, M.; Mackowiak, C.; Comerford, N.; Moline, E.; Shirley, J.; Guimaraes, D. Pyrolysis methods impact biosolids-derived biochar composition, maize growth and nutrition. Soil Tillage Res. 2017, 165, 59-65. [CrossRef]

178. Zhao, S.; Na, T.; Li, Z.; Yang, Y.; Zhang, X.; Liu, D.; Zhang, A.; Wang, X. Varying pyrolysis temperature impacts application effects of biochar on soil labile organic carbon and humic fractions. Appl. Soil Ecol. 2018, 123, 484-493. [CrossRef]

179. Khorram, M.; Zheng, Y.; Lin, D.; Zhang, Q.; Fang, H.; Yu, Y. Dissipation of fomesafen in biochar-amended soil and its availability to corn (Zea mays L.) and earthworm (Eisenia fetida). J. Soils Sediments 2016, 16, 2439-2448. [CrossRef]

180. Dechene, A.; Rosendahl, I.; Laabs, V.; Amelung, W. Sorption of polar herbicides and herbicide metabolites by biochar amended soil. Chemosphere 2014, 109, 180-186. [CrossRef] [PubMed]

181. García-Jaramillo, M.; Cox, L.; Cornejo, J.; Hermosín, M. Effect of soil organic amendments on the behavior of bentazone and tricyclazole. Sci. Total Environ. 2014, 466-467, 906-913. [CrossRef] [PubMed]

182. Khorram, M.; Wang, Y.; Jin, X.; Fang, H.; Yu, Y. Reduced mobility of fomesafen through enhanced adsorption in biochar-amended soil. Environ. Toxicol. Chem. 2015, 34, 1258-1266. [CrossRef]

183. Deng, H.; Feng, D.; He, J.; Li, F.; Yu, H.; Ge, C. Influence of biochar amendments to soil on the mobility of atrazine using sorption-desorption and soil thinlayer chromatography. Ecol. Eng. 2017, 99, 381-390. [CrossRef]

184. Wang, H.; Lin, K.; Hou, Z.; Richardson, B.; Gan, J. Sorption of the herbicide terbuthylazine in two New Zealand forest soils amended with biosolids and biochars. J. Soils Sediments 2010, 10, 283-289. [CrossRef]

185. Zhang, X.; Sarmah, A.; Bolan, N.; He, L.; Lin, X.; Che, L.; Tang, C.; Wang, H. Effect of aging process on adsorption of diethyl phthalate in soils amended with bamboo biochar. Chemosphere 2016, 142, 28-34. [CrossRef]

186. Lou, L.; Luo, L.; Cheng, G.; Wei, Y.; Mei, R.; Xun, B.; Xu, X.; Hu, B.; Chen, Y. The sorption of pentachlorophenol by aged sediment supplemented with black carbon produced from rice straw and fly ash. Bioresour. Technol. 2012, 112, 61-66. [CrossRef]

187. Khorram, M.; Lin, D.; Zhang, Q.; Zheng, Y.; Fang, H.; Yu, Y. Effects of aging process on adsorption-desorption and bioavailability of fomesafen in an agricultural soil amended with rice hull biochar. J. Environ. Sci. 2017, 56, 180-191. [CrossRef]

188. Semidaa, W.; Beheirya, H.; Setamou, M.; Simpsonb, C.; El-Mageed, T.A.; Radyd, M.; Nelson, S. Biochar implications for sustainable agriculture and environment: A review. S. Afr. J. Bot. 2019, 127, 333-347. [CrossRef]

189. Lee, J.; Hawkins, B.; Day, D.; Reicosky, D. Sustainability: The capacity of smokeless biomass pyrolysis for energy production, global carbon capture and sequestration. Energy Environ. Sci. 2010, 3, 1695-1705. [CrossRef]

190. Kumar, S.; Masto, R.E.; Ram, L.C.; Sarkar, P.; George, J.; Selvi, V.A. Biochar preparation from parthenium hysterophorus and its potential use in soil application. Ecol. Eng. 2013, 55, 67-72. [CrossRef]

191. Xu, G.; Wei, L.; Sun, J.; Shao, H.; Chang, S. What is more important for enhancing nutrient bioavailability with biochar application into a sandy soil: Direct or indirect mechanism? Ecol. Eng. 2012, 52, 119-124. [CrossRef]

192. Spokas, K.; Reicosky, D. Impacts of sixteen different biochars on soil greenhouse gas production. Ann. Environ. Sci. 2009, 3 , 179-193. 
193. Liu, Y.; Yang, M.; Wu, Y.; Wang, H.; Chen, Y.; Wu, W. Reducing $\mathrm{CH}_{4}$ and $\mathrm{CO}_{2}$ emissions from waterlogged paddy soil with biochar. J. Soils Sediments 2011, 11, 930-939. [CrossRef]

194. Major, J.; Lehmann, J.; Rondon, M.; Goodale, C. Fate of soil-applied black carbon: Downward migration, leaching and soil respiration. Glob. Chang. Biol. 2010, 16, 1366-1379. [CrossRef]

195. Bell, M.; Worrall, F. Charcoal addition to soils in New England: A carbon sink with environmental co-benefits? Sci. Total Environ. 2011, 409, 1704-1714. [CrossRef] [PubMed]

196. Karhu, K.; Mattila, T.; Bergstrom, I.; Regina, K. Biochar addition to agricultural soil increased $\mathrm{CH}_{4}$ uptake and water holding capacity-Results from a short-term pilot field study. Agric. Ecosyst. Environ. 2011, 140, 309-313. [CrossRef]

197. Rogovska, N.; Laird, D.; Cruse, R.; Fleming, P.; Parkin, T.; Meek, D. Impact of biochar on manure carbon stabilization and greenhouse gas emissions. Soil Sci. Soc. Am. J. 2011, 75, 871-879. [CrossRef]

198. Zhang, A.; Bian, R.; Pan, G.; Cui, L.; Hussain, Q.; Li, L.; Zheng, J.; Zheng, J.; Zhang, X.; Han, X.; et al. Effects of biochar amendment on soil quality, crop yield and greenhouse gas emission in a chinese rice paddy: A field study of 2 consecutive rice growing cycles. Field Crop. Res. 2012, 127, 153-160. [CrossRef]

199. Zimmerman, A.; Gao, B.; Ahn, M. Positive and negative carbon mineralization priming effects among a variety of biocharamended soils. Soil Biol. Biochem. 2011, 43, 1169-1179. [CrossRef]

200. Dong, D.; Yang, M.; Wang, C.; Wang, H.; Li, Y.; Luo, J.; Wu, W. Responses of methane emissions and rice yield to applications of biochar and straw in a paddy field. J. Soils Sed. 2013, 13, 1-11. [CrossRef]

201. Chen, D.; Wang, C.; Shen, J.; Li, Y.; Wu, J. Response of $\mathrm{CH}_{4}$ emissions to straw and biochar applications in double-rice cropping systems: Insights from observations and modeling. Environ. Pollut. 2018, 235, 95-103. [CrossRef] [PubMed]

202. Ibrahim, A.; Usman, A.; Al-Wabel, M.; Nadeem, O.-Y.; Al-Omran, M.A. Effects of conocarpus biochar on hydraulic properties of calcareous sandy soil: Influence of particle size and application depth. Arch. Agron. Soil Sci. 2017, 63, 185-197. [CrossRef]

203. Cayuela, M.; Sánchez-Monedero, M.; Roig, A.; Hanley, K.; Enders, A.; Lehmann, J. Biochar and denitrification in soils: When, how much and why does biochar reduce $\mathrm{N}_{2} \mathrm{O}$ emissions? Sci. Rep. 2013, 3, 542. [CrossRef] [PubMed]

204. Harter, J.; Weigold, P.; El-Hadidi, M.; Huson, D.; Kappler, A.; Behrens, S. Soil biochar amendment shapes the composition of $\mathrm{N}_{2} \mathrm{O}$-reducing microbial communities. Sci. Total Environ. 2016, 562, 379-390. [CrossRef] [PubMed]

205. Brassard, P.; Godbout, S.; Raghavan, V. Soil biochar amendment as a climate change mitigation tool: Key parameters and mechanisms involved. J. Environ. Manag. 2016, 181, 484-497. [CrossRef] [PubMed]

206. Harter, J.; Krause, H.-M.; Schuettler, S.; Ruser, R.; Fromme, M.; Scholten, T.; Kappler, A.; Behrens, S. Linking $\mathrm{N}_{2} \mathrm{O}$ emissions from biochar-amended soil to the structure and function of the N-cycling microbial community. ISME J. 2014, 8, 660-674. [CrossRef] [PubMed]

207. Zhang, A.; Liu, Y.; Pan, G.; Hussain, Q.; Li, L.; Zheng, J.; Zhang, X. Effect of biochar amendment on maize yield and greenhouse gas emissions from a soil organic carbon poor calcareous loamy soil from central china plain. Plant Soil 2012, 351, $263-275$. [CrossRef]

208. Scheer, C.; Grace, P.; Rowlings, D.; Kimber, S.; van Zwieten, L. Effect of biochar amendment on the soil atmosphere exchange of greenhouse gases from an intensive subtropical pasture in northern new south wales, Australia. Plant Soil 2011, 345, 47-58. [CrossRef]

209. Zhang, A.; Cui, L.; Pana, G.; Li, L.; Hussaina, Q.; Zhanga, X.; Zhenga, J.; Crowley, D. Effect of biochar amendment on yield and methane and nitrous oxide emissions from a rice paddy from tai lake plain, china. Agric. Ecosyst. Environ. 2010, 139, 469-475. [CrossRef]

210. European Biochar Certificate (EBC) I Guidelines for A Sustainable Production of Biochar, Version 8.2. Available online: http: / / www.european-biochar.org/en/download (accessed on 19 April 2019).

211. Gerlach, A.; Schmidt, H. Pflanzenkohle in der Rinderhaltung. Ithaka J. 2012, 1, 80-84.

212. European Biochar Certificate (EBC), Guidelines for EBC-Feed Certification. Available online: http://www.europeanbiochar.org/ biochar/media/doc/ebc-feed.pdf (accessed on 4 April 2019).

213. Schmidt, H.P.; Kammann, C.I.; Gerlach, A.; Gerlach, H. Der Einsatz von Pflanzenkohle in der Tierfütterung. Ithaka J. 2016, 95, 364-394.

214. O'Toole, A.; Andersson, D.; Gerlach, A.; Glaser, B.; Kammann, C.; Kern, J.; Kuoppamäki, K.; Mumme, J.; Schmidt, H.-P.; Schulze, M.; et al. Current and future applications for biochar. In Biochar in European soils and Agriculture: Science and Practice; Shackley, S., Ruysschaert, G., Zwart, K., Glaser, B., Eds.; Taylor Francis Group: London, UK, 2016; pp. 253-280.

215. Toth, J.; Dou, Z. Use and impact of biochar and charcoal in animal production systems. In Agricultural and Environmental Applications of Biochar: Advances and Barriers; Guo, M., He, Z., Uchimiya, S.M., Eds.; Soil Science Society of America, Inc: Madison, MA, USA, 2016; Volume 63, pp. 199-224.

216. Devi, P.; Saroha, A. Synthesis of the magnetic biochar composites for use as an adsorbent for the removal of pentachlorophenol from the effluent. Bioresour. Technol. 2014, 169, 525-531. [CrossRef]

217. Lecroy, C.; Masiello, C.; Rudgers, J.; Hockaday, W.; Silberg, J. Nitrogen, biochar, and mycorrhizae: Alteration of the symbiosis and oxidation of the char surface. Soil Biol. Biochem. 2013, 58, 248-254. [CrossRef]

218. Enders, A.; Hanley, K.; Whitman, T.; Joseph, S.; Lehmann, J. Characterization of biochars to evaluate recalcitrance and agronomic performance. Bioresour. Technol. 2012, 114, 644-653. [CrossRef] [PubMed] 
219. Barman, H.; Roy, A.; Das, S. Evaluation of plant products and antagonistic microbes against grey blight (pestalotiopsistheae), a devastating pathogen of tea. Afr. J. Microb. Res. 2015, 9, 1263-1267.

220. Zhang, J.; Lü, F.; Luo, C.; Shao, L.; He, P. Humification characterization of biochar and its potential as a composting amendment. J. Environ. Sci. 2014, 26, 390-397. [CrossRef]

221. Hagemann, N.; Subdiaga, E.; Orsetti, S.; de la Rosa, J.; Knicker, H.; Schmidt, H.; Kappler, A.; Behrens, S. Effect of biochar amendment on compost organic matter composition following aerobic composting of manure. Sci. Total Environ. 2018, 613-614, 20-29. [CrossRef]

222. Guo, X.; Liu, H.; Zhang, J. The role of biochar in organic waste composting and soil improvement: A review. J. Waste Manag. 2020, 102, 884-899. [CrossRef]

223. Khorram, M.; Zhang, G.; Fatemi, A.; Kiefer, R.; Maddah, K.; Baqar, M.; Zakaria, M.; Li, G. Impact of biochar and compost amendment on soil quality, growth and yield of a replanted apple orchard in a 4-year field study. J. Sci. Food Agric. 2019, 99, 1862-1869. [CrossRef]

224. Glaba, T.; Żabiński, A.; Sadowska, U.; Gondek, K.; Kopeć, M.; Mierzwa-Hersztek, M.; Tabor, S. Effects of co-composted maize, sewage sludge, and biochar mixtures on hydrological and physical qualities of sandy soil. Geoderma 2018, 315, 27-35. [CrossRef]

225. Kammann, C.; Schmidt, H.; Messerschmidt, N.; Linsel, S.; Steffens, D.; Muller, C.; Koyro, H.; Conte, P.; Joseph, S. Plant growth improvement mediated by nitrate capture in co-composted biochar. Sci. Rep. 2015, 5, 11080. [CrossRef]

226. Xiao, R.; Awasthi, M.; Li, R.; Park, J.; Pensky, S.; Wang, Q.; Wang, J.; Zhang, Z. Recent developments in biochar utilization as an additive in organic solid waste composting: A review. Bioresour. Technol. 2017, 246, 203-213. [CrossRef]

227. Sánchez-García, M.; Alburquerque, J.; Sánchez-Monedero, M.; Roig, A.; Cayuela, M. Biochar accelerates organic matter degradation and enhances $\mathrm{n}$ mineralisation during composting of poultry manure without a relevant impact on gas emissions. Bioresour. Technol. 2015, 192, 272-279. [CrossRef]

228. Godlewska, P.; Schmidt, H.; Ok, Y.; Oleszczuk, P. Biochar for composting improvement and contaminants reduction. A review. Bioresour. Technol. 2017, 246, 193-202. [CrossRef] [PubMed]

229. Zhang, J.; Chen, G.; Sun, H.; Zhou, S.; Zou, G. Straw biochar hastens organic matter degradation and produces nutrient-rich compost. Bioresour. Technol. 2016, 200, 876-883. [CrossRef] [PubMed]

230. Otterpohl, R. Boosting compost with biochar and bacteria. Nature 2012, 486, 187-188.

231. Jindo, K.; Sonoki, T.; Matsumoto, K.; Matsumoto, K.; Canellas, L.; Roig, A.; Sanchez-Monedero, M.A. Influence of biochar addition on the humic substances of composting manures. Waste Manag. 2016, 49, 545-552. [CrossRef]

232. Awasthi, M.; Awasthi, S.; Wang, Q.; Wang, Z.; Lahori, A.; Ren, X.; Chen, H.; Wang, M.; Zhao, J.; Zhang, Z. Influence of biochar on volatile fatty acids accumulation and microbial community succession during biosolids composting. Bioresour. Technol. 2018, 251, 158-164. [CrossRef]

233. Awasthi, M.; Wang, M.; Chen, H.; Wang, Q.; Zhao, J.; Ren, X.; Li, D.; Awasthi, S.; Shen, F.; Li, R.; et al. Heterogeneity of biochar amendment to improve the carbon and nitrogen sequestration through reduce the greenhouse gases emissions during sewage sludge composting. Bioresour. Technol. 2017, 224, 428-438. [CrossRef]

234. deMelo, B.; Motta, F.; Santana, M. Humic acids: Structural properties and multiple functionalities for novel technological developments. Mater. Sci. Eng. C 2016, 62, 967-974. [CrossRef]

235. Jain, M.; Jambhulkar, R.; Kalamdhad, A. Biochar amendment for batch composting of nitrogen rich organic waste: Effect on degradation kinetics, composting physics and nutritional properties. Bioresour. Technol. 2018, 253, 204-213. [CrossRef] [PubMed]

236. Zhang, L.; Sun, X. Changes in physical, chemical, and microbiological properties during the two-stage co-composting of green waste with spent mushroom compost and biochar. Bioresour. Technol. 2014, 171, 274-284. [CrossRef]

237. Wu, S.; Shen, Z.; Yang, C.; Zhou, Y.; Li, X.; Zeng, G.; Ai, S.; He, H. Effects of C/N ratio and bulking agent on speciation of Zn and $\mathrm{Cu}$ and enzymatic activity during pig manure composting. Int. Biodeterior. Biodegrad. 2016, 119, 429-436. [CrossRef]

238. Wiedner, K.; Fischer, D.; Walther, S.; Criscuoli, I.; Favilli, F.; Nelle, O.; Glaser, B. Acceleration of biochar surface oxidation during composting? J. Agric. Food Chem. 2015, 63, 3830-3837. [CrossRef]

239. Oldfield, T.; Sikirica, N.; Mondini, C.; López, G.; Kuikman, P.; Holden, N. Biochar, compost and biochar-compost blend as options to recover nutrients and sequester carbon. J. Environ. Manag. 2018, 218, 465-476. [CrossRef]

240. Steiner, C.; Das, K.; Melear, N.; Lakly, D. Reducing nitrogen loss during poultry litter composting using biochar. J. Environ. Qual. 2010, 39, 1236-1242. [CrossRef]

241. Chowdhury, M.; de Neergaard, A.; Jensen, L. Potential of aeration flow rate and bio-char addition to reduce greenhouse gas and ammonia emissions during manure composting. Chemosphere 2014, 97, 16-25. [CrossRef]

242. Sanchez-Monedero, M.; Cayuela, M.; Roig, A.; Jindo, K.; Mondini, C.; Bolan, N. Role of biochar as an additive in organic waste composting. Bioresour. Technol. 2018, 247, 1155-1164. [CrossRef] [PubMed]

243. Lou, L.; Huang, Q.; Lou, Y.; Lu, J.; Hu, B.; Lin, Q. Adsorption and degradation in the removal of nonylphenol from water by cells immobilized on biochar. Chemosphere 2019, 228, 676-684. [CrossRef] [PubMed]

244. Varjani, S.; Kumar, G.; Rene, E. Developments in biochar application for pesticide remediation: Current knowledge and future research directions. J. Environ. Manag. 2019, 232, 505-513. [CrossRef] [PubMed]

245. Liu, N.; Zhou, J.; Han, L.; Ma, S.; Sun, X.; Huang, G. Role and multi-scale characterization of bamboo biochar during poultry manure aerobic composting. Bioresour. Technol. 2017, 241, 190-199. [CrossRef] [PubMed] 
246. Wang, C.; Lu, H.; Dong, D.; Deng, H.; Strong, P.; Wang, H.; Wu, W. Insight into the effects of biochar on manure composting: Evidence supporting the relationship between $\mathrm{N}_{2} \mathrm{O}$ emission and denitrifying community. Environ. Sci. Technol. 2013, 47, 7341-7349. [CrossRef]

247. Malinowski, M.; Wolny-Koladka, K.; Vaverkovà, M. Effect of biochar addition on the OFMSW composting process under real conditions. Waste Manag. 2019, 84, 364-372. [CrossRef] [PubMed]

248. Jindo, K.; Suto, K.; Matsumoto, K.; Garcia, C.; Sonoki, T.; Sanchez-Monedero, M. Chemical and biochemical characterisation of biochar-blended composts prepared from poultry manure. Bioresour. Technol. 2012, 110, 396-404. [CrossRef] [PubMed]

249. Du, J.; Zhang, Y.; Hu, B.; Qv, M.; Ma, C.; Wei, M.; Zhang, H. Insight into the potentiality of big biochar particle as an amendment in aerobic composting of sewage sludge. Bioresour. Technol. 2019, 288, 121469. [CrossRef]

250. Zhou, H.; Meng, H.; Zhao, L.; Shen, Y.; Hou, Y.; Cheng, H.; Song, L. Effect of biochar and humic acid on the copper, lead, and cadmium passivation during composting. Bioresour. Technol. 2018, 258, 279-286. [CrossRef]

251. Liu, W.; Huo, R.; Xu, J.; Liang, S.; Li, J.; Zhao, T.; Wang, S. Effects of biochar on nitrogen transformation and heavy metals in sludge composting. Bioresour. Technol. 2017, 235, 43-49. [CrossRef]

252. Wang, Q.; Awasthi, M.; Ren, X.; Zhao, J.; Li, R.; Wang, Z.; Chen, H.; Wang, M.; Zhang, Z. Comparison of biochar, zeolite and their mixture amendment for aiding organic matter transformation and nitrogen conservation during pig manure composting. Bioresour. Technol. 2017, 245, 300-308. [CrossRef]

253. Agyarko-Mintah, E.; Cowie, A.; Singh, B.; Joseph, S.; Van Zwieten, L.; Cowie, A.; Harden, S.; Smillie, R. Biochar increases nitrogen retention and lowers greenhouse gas emissions when added to composting poultry litter. Waste Manag. 2017, 61, 138-149. [CrossRef]

254. Wang, Q.; Awasthi, M.; Ren, X.; Zhao, J.; Li, R.; Wang, Z.; Wang, M.; Chen, H.; Zhang, Z. Combining biochar, zeolite and wood vinegar for composting of pig manure: The effect on greenhouse gas emission and nitrogen conservation. Waste Manag. 2018, 74, 221-230. [CrossRef] [PubMed]

255. Czekała, W.; Malinska, K.; Caceres, R.; Janczak, D.; Dach, J.; Lewicki, A. Co-composting of poultry manure mixtures amended with biochar-The effect of biochar on temperature and $\mathrm{C}-\mathrm{CO}_{2}$ emission. Bioresour. Technol. 2016, 200, 921-927. [CrossRef] [PubMed]

256. Zhu, Q.; Peng, X.; Huang, T. Contrasted effects of biochar on maize growth and $\mathrm{N}$ use efficiency depending on soil conditions. Int. Agrophys. 2015, 29, 257-266. [CrossRef]

257. Anyanwu, I.; Alo, M.; Onyekwere, A.; Crosse, J.; Nworie, O.; Chamba, E. Influence of biochar aged in acidic soil on ecosystem engineers and two tropical agricultural plants. Ecotoxicol. Environ. Saf. 2018, 153, 116-126. [CrossRef]

258. SafaeiKhorram, M.; Fatemi, A.; Khan, M.; Kiefer, R.; Jafarnia, S. Potential risk of weed outbreak by increasing biochar's application rates in slow-growth legume, lentil (Lens culinaris Medik.). J. Sci. Food Agric. 2018, 98, 2080-2088. [CrossRef]

259. Vaccari, F.; Maienza, A.; Miglietta, F.; Baronti, S.; Di Lonardo, S.; Giagnoni, L.; Lagomarsino, A.; Pozzi, A.; Pusceddu, E.; Ranieri, R. biochar stimulates plant growth but not fruit yield of processing tomato in a fertile soil. Agric. Ecosyst. Environ. 2015, 207, 163-170. [CrossRef]

260. Hol, W.; Vestergård, M.; ten Hooven, F.; Duyts, H.; van de Voorde, T.; Bezemer, T. Transient negative biochar effects on plant growth are strongest after microbial species loss. Soil Biol. Biochem. 2017, 115, 442-451. [CrossRef]

261. Denyes, M.; Rutter, A.; Zeeb, B. Bioavailability assessments following biochar and activated carbon amendment in DDTcontaminated soil. Chemosphere 2016, 144, 1428-1434. [CrossRef]

262. Butnan, S.; Deenik, J.; Toomsan, B.; Antal, M.; Vityakon, P. Biochar characteristics and application rates affecting corn growth and properties of soils contrasting in texture and mineralogy. Geoderma 2015, 237, 105-116. [CrossRef]

263. Kim, H.; Kim, K.; Kim, H.; Yoon, J.; Yang, J.; Ok, Y.; Owens, G.; Kim, K. Effect of biochar on heavy metal immobilization and uptake by lettuce (Lactuca sativa L.) in agricultural soil. Environ. Earth Sci. 2015, 74, 1249-1259. [CrossRef]

264. Joseph, S.; Kammann, C.; Shepherd, J.; Conte, P.; Schmidt, H.; Hagemann, N.; Rich, A.; Marjo, C.; Allen, J.; Munroe, P.; et al. Microstructural and associated chemical changes during the composting of a high temperature biochar: Mechanisms for nitrate, phosphate and other nutrient retention and release. Sci. Total Environ. 2018, 618, 1210-1223. [CrossRef] [PubMed]

265. Zheng, J.; Chen, J.; Pan, G.; Liu, X.; Zhang, X.; Li, L.; Bian, R.; Cheng, K.; Jinwei, Z. Biochar decreased microbial metabolic quotient and shifted community composition four years after a single incorporation in a slightly acid rice paddy from southwest china. Sci. Total Environ. 2016, 571, 206-217. [CrossRef] [PubMed]

266. Gonzaga, M.; Mackowiak, C.; de Almeida, A.; de Carvalho Junior, J.; Andrade, K. Positive and negative effects of biochar from coconut husks, orange bagasse and pine wood chips on maize (Zea mays L.) growth and nutrition. Catena 2018, 162, 414-420. [CrossRef]

267. Jones, D.; Quilliam, R. Metal contaminated biochar and wood ash negatively affect plant growth and soil quality after land application. J. Hazard. Mater. 2014, 276, 362-370. [CrossRef] [PubMed] 